ISSN: 0213-2079 - ISSN electrónico: 2386-3889

DOI: https://doi.org/10.14201/shhmo2017392115152

\title{
EL TRASLADO DE LA CASA DE LA CONTRATACIÓN Y DEL CONSULADO DE INDIAS Y SUS EFECTOS EN EL CONTEXTO DE LA NUEVA PLANTA DE LA MARINA Y DEL COMERCIO AMERICANO
}

The Transfer of the Casa de la Contratacion and the Consulado de Indias and their Effects in the Context of the Nueva Plant of the Navy and the American Trade

\section{Manuel BUSTOS RODRÍGUEZ}

Universidad de Cádiz

Correo-e: manuel.bustos@uca.es

RESUMEN: El traslado de la Casa de la Contratación y del Consulado desde Sevilla a Cádiz en 1717 forma parte de un proyecto combinado de reforma de la Marina y del comercio con América, a desarrollar en las siguientes décadas, tomando como centro la bahía de Cádiz. Este artículo analiza los elementos que influyeron en esta elección de la Corona, el protagonismo de Patiño y de otros ministros en la reforma, el desarrollo de la misma y los principales conflictos surgidos alrededor entre 1720 y 1750 aproximadamente.

Palabras clave: Casa de la Contratación; Consulado; Felipe V; Marina; comercio; Cádiz.

ABSTRACT: The transfer of the Casa de la Contratacion and the Consulado from Seville to Cadiz in 1717 is part of a combined reform project of the Navy and trade with America, to be developed in the following decades, taking as a center the bay of Cadiz. This article analyzes the elements that influenced this election of the Crown, the role of Patiño and

Ediciones Universidad de Salamanca / 뾰 Stud. his., H. ${ }^{a}$ mod., 39, n. 2 (2017), pp. 115-152 
other ministers in the reform, their development and the main conflicts that arose between around 1720 and 1750.

Key words: Casa de la Contratación; Consulado; Felipe V; Marine; Trade; Cádiz.

\section{El contexto Político}

La muerte del último de los Habsburgo en el trono español sin descendencia, provocó una larga guerra de 14 años (1701-1715). Los años del conflicto y la posterior victoria del nieto de Luis XIV, Felipe de Anjou, sobre su rival de la Casa de Austria introducirá cambios sustanciales a corto y largo plazo en el sistema político-administrativo español hasta entonces vigente. De allí saldrán los llamados decretos de la Nueva Planta, así como otros, afectando a la Administración general (secretarías en sustitución de algunos consejos, intendencias, etc.) y a la concepción misma del Poder. La monarquía de poder compartido y descentralizado dará paso a otra de carácter más uniforme, centralizada política, jurídica y administrativamente y, si se quiere, de un corte más «nacional». Un tanto exageradamente, podríamos hablar incluso de un nuevo paradigma estatal ${ }^{1}$.

Evidentemente, aunque impulsados por el rey, estos cambios fueron producto de la intervención de sus ministros, pero también de las influencias de los grupos, que, desde la época de Carlos II, circulaban por la Corte $^{2}$, y más tarde de ciertas personalidades adscritas en mayor o menor medida a los intereses de sus países de origen (Ursinos, Farnesio, Alberoni o Ripperdá), que ejercían una importante influencia ante un monarca dependiente de sus apoyos externos.

La historiografía española suele distinguir al respecto tres períodos, aunque en todos ellos se perciban mezclas y en el seno de cada uno se fragüen los protagonistas del siguiente. El primero, bajo la influencia francesa, coincidente sobre todo con los años iniciales de la guerra, cuando se hacía más necesario el apoyo de Luis XIV para obtener la victoria. Luego, a medida que se acercaba la paz y

1. Vid. a ese respecto de Bernardo Ares, J. M.: «La Monarquía Hispánica de Ryswick y el Estado Español de Utrecht: dos formas diferentes de configurar política y económicamente a España», en Pereira, J. L. (coord.): Felipe V de Borbón 1701-1746. Actas (Congreso San Fernando (Cádiz) de 27 de noviembre a 1 de diciembre de 2000). Córdoba, Ayuntamiento de San Fernando y Universidad de Córdoba, 2002, pp. 503-518.

2. Cfr. Ribot García, L. A.: «Orígenes políticos del testamento de Carlos II. La gestación del cambio dinástico en España. Discurso leído el día 17 de octubre de 2010 en la recepción pública...». Madrid, 2010. 
los ingleses parecían más próximos a verse favorecidos, las autoridades francesas intensificarían su celo por mantener sus prerrogativas, sobre todo en el terreno comercial. Junto al interés por sentar en el trono español a un monarca de la rama Borbón, estuvo presente desde el primer momento el deseo de conseguir una mejor penetración en los mercados hispanoamericanos. Así lo muestran las instrucciones recibidas por los enviados a España por Luis XIV, donde es omnipresente esta preocupación ${ }^{3}$.

En el primer escrito localizado al respecto de este período, instruyendo al cardenal d'Estrées en 1703, se le señala como objetivo a conseguir durante su estancia en España un estatus comercial ventajoso para Francia, por encima del que pudiesen lograr para sí las otras potencias implicadas en el conflicto. Tras recordarle que dicho comercio con América «produit la plus grande partie de l'argent qui se répand dans tous les autres Etats de l'Europe», le pide una «attention particulière» para aumentarlo por todos los medios, atendiendo las sugerencias de sus negociantes en la Península y aprovechando asimismo el nombre del rey de Francia cuando fuere necesario. Y es que se trataba del comercio más importante -se le recuerda-, del que proporciona a Francia más plata, aprovechando la débil industria española ${ }^{4}$.

De hecho, desde 1701, la idea de Luis XIV era que su embajador en Madrid actuase como si fuera un ministro de la Corona española ${ }^{5}$. Y ello sin olvidarse de proporcionar a su nieto la persona de Jean Orry y a la princesa de los Ursinos, situada como camarera mayor de la reina, facilitando su influencia sobre la familia real ${ }^{6}$. No contento con ello, tras crearse el Consejo de Despacho, extraño a la tradición española de los Austrias, situará dentro de él a hombres de su hechura, como Portocarrero, a la sazón presidente del Consejo de Castilla, el embajador de Francia y Ubilla en el papel de secretario. Dicho Consejo, que entendía en asuntos importantes, no era sino «la tapadera legal del embajador de Francia para, en colaboración con Ursinos, actuar de acuerdo con Luis XIV» ${ }^{7}$. Durante las

3. Ozanam, D. y Mézin, A.: Économie et négoce des Français dans l'Espagne de l'Époque Moderne. Instructions et mémoires officiels relatifs au commerce en Espagne de la gestion de Colbert (1669) au Pacte de Famille (1761). París, 2011.

4. Idem, p. 56. Los consejos que recibirá apenas ocho años después, en 1711, el enviado extraordinario del rey de Francia, marqués de Bonnac, serán prácticamente una copia de los anteriores (Ibidem, p. 114).

5. Castellano, J. L.: «El gobierno en los primeros años del reinado de Felipe V: La influencia francesa», en Pereira, J. L. (coord.): Felipe V de Borbón 1701-1746, p. 134.

6. Juan Luis Castellano compara el poder adquirido por ambos personajes con el de los validos, Lerma y Olivares, haciéndoles equivalentes.

7. Castellano, J. L.: art. cit., pp. 135 y 137.

Ediciones Universidad de Salamanca / 요 Stud. his., H. ${ }^{a}$ mod., 39, n. 2 (2017), pp. 115-152 
obligadas ausencias de Felipe $\mathrm{V}$ de la Corte, la influencia francesa en la primera administración borbónica crecería, a través de la Junta de Gobierno, de carácter provisional.

Tras el período francés, seguirá un segundo de influencia italiana de la mano de la esposa de Felipe V, Isabel de Farnesio, del que luego nos ocuparemos más ampliamente. Por último, hay un tercero, en el cual, sin desaparecer del todo los nombres extranjeros, se impondrán los nacionales.

Esta frecuencia de la presencia extranjera en los dos primeros períodos deberá mucho al hueco dejado por la incorporación al bando austracista de españoles cualificados que habían ocupado puestos importantes antes de la guerra en la Administración, pero que hubieron de abandonarlos tras el triunfo borbónico, tema aún poco desbrozado. También el propio carácter extranjero del monarca y de la nueva dinastía, empujaban a echar mano, siquiera en los primeros tiempos, de personas de su entorno político y confianza.

Así, el período francés coincide en la Corte con personajes como el citado financiero Jean Orry, organizador de la Real Hacienda en esos años desbarajustados $^{8}$, y el superembajador Michel-Jean Amelot de Gounay. Al cabo, desalojada del poder la princesa de los Ursinos, protectora de los franceses, se impone la línea italianista con Farnesio, su antagonista, y el ministro Alberoni al frente, que promocionan una política de corte mediterráneo y elevan a cargos importantes a hombres como Grimaldo o los hermanos milaneses José y Baltasar Patiño. Dentro de esta etapa forjará a la vez una nueva generación, la correspondiente a la tercera etapa, formada por españoles, entre los que destacan nombres como Campillo y Cossío o Francisco Zenón, futuro marqués de la Ensenada, todos ellos de gran importancia para la promoción de Cádiz y su bahía.

La firma del tratado de Utrecht entre España e Inglaterra el 13 de julio de 1713 puso fin oficialmente al conflicto, aunque se continuase combatiendo aún algunos años más en el frente de Cataluña y quedaran en espera la firma de otros tratados más secundarios. Los resultados de la paz, como sabemos, fueron muy favorables para los británicos, que conservaron bases importantes en el Mediterráneo (Gibraltar desde 1704 y Menorca desde 1708) y una participación sustancial en el monopolio comercial de España con América («navío de permiso» y suministro de negros a las colonias españolas). El 9 de noviembre de 1713 se firmaba entre ambos países un Tratado de Navegación que confirmaba tales ventajas.

8. De su actuación entre 1701-1705: Hanotin, G.: Jean Orry. Un homme des finances royales entre France et Espagne (1701-1705). Córdoba, 2009. 
Por el contrario, España perdía, en esta ocasión en favor del Imperio Austriaco, sus territorios italianos, así como lo que aún le restaba de los Países Bajos del Sur. Por unas y otras razones, el control del acceso desde el Mediterráneo al Atlántico cobraba ahora para ella un especial valor estratégico.

Para más acrecentarlo, con la llegada de Isabel de Farnesio y los gobiernos de Alberoni, la Monarquía hispánica concentraría sus esfuerzos en la recuperación de sus territorios italianos, lo que le introdujo en una concatenación de conflictos sucesivos contra las nuevas alianzas (en la que se incluirá durante algún tiempo su antigua aliada, Francia), que no cesaron hasta la firma del tratado de Viena en 1725. Consecuente con todos estos cambios, Cádiz y su bahía reforzaron el valor estratégico que ya poseían desde antes.

Sin embargo, la política italiana impulsada por Isabel no impediría que la idea de algunos ministros de Felipe $\mathrm{V}$ sobre la necesidad de fijar los ojos en el Atlántico y, de manera particular, en América, coincidiendo el menor peso de los compromisos europeos, siguiera adelante. A medida que el grupo de ministros de origen hispano fortalecía su presencia en el Poder, se reforzada esta preocupación. La conciencia, claramente mercantilista, de que el «necesario Curso de los Comercios (es el) fundamento único de la opulencia de las Monarquías»" animó a la Corona a buscar una actuación política, tanto por intereses económicos como fiscales. Así, la razón estratégica, unida al deseo de un mejor aprovechamiento colonial, convergieron sobre la necesidad de incidir en el viejo monopolio de Indias y la política naval, vista la complementariedad existente entre ambas. Sin embargo, la envergadura de las reformas a llevar a cabo era muy grande y las dificultades enormes.

\section{LAS PRIMERAS INICIATIVAS}

La convicción acerca de esta realidad llevaría a las autoridades españolas, incluso en plena guerra, a dar los primeros pasos a fin de adoptar las medidas necesarias. Inicialmente irán sobre todo dirigidas a la reforma de la Marina, que el decurso del conflicto había mostrado como de especial urgencia; pero sin dejar en el tintero probablemente el abordaje de asuntos relacionados con el comercio, por entonces en situación complicada a causa de la guerra. La primera junta convocada a tal efecto de que tengamos constancia data de 1708, aunque no tuviese carácter

9. Así viene a expresarse unos años después con nitidez en el texto del Proyecto para galeones y flotas del Perú, y Nueva España, y para navios de registro, y avisos, que navegaren a ambos Reynos. Año de 1720. Impresso: De orden del Rey, fol. 3.

Ediciones Universidad de Salamanca / 요 Stud. his., H. ${ }^{a}$ mod., 39, n. 2 (2017), pp. 115-152 
MANUEL BUSTOS RODRÍGUEZ

EL TRASLADO DE LA CASA DE LA CONTRATACIÓN Y DEL CONSULADO DE INDIAS Y SUS EFECTOS

EN EL CONTEXTO DE LA NUEVA PLANTA DE LA MARINA Y DEL COMERCIO AMERICANO

resolutivo ${ }^{10}$. Paralelamente, en ese mismo año se decidiría reagrupar una parte importante de las armadas existentes, sin que conozcamos la relación de la medida con dicha junta; eso sí, habría de esperar a su aplicación.

Pero hasta el final de la guerra no se darían pasos sustanciales para la reforma de la Armada. Como anticipo, a instancias del conde Bergeyck, recién llegado de las negociaciones de Utrecht en representación de Felipe V, se reunirán Orry y Bernardo Tinajero para estudiar su propuesta de restaurar la Marina ${ }^{11}$.

De la reunión, cuya fecha exacta desconocemos, más que una estrategia global resultaron varias decisiones de urgencia: la compra de buques de guerra en el extranjero y la construcción a la vez de seis navíos en los astilleros vizcaínos. Inicialmente la idea de Tinajero había sido la de fomentar la construcción naval en centros hispanos, especialmente en el astillero de La Habana, encargándose al almirante Manuel López Pintado de proveer a la construcción de diez bajeles, mediante el sistema de asiento ${ }^{12}$. Pero, al parecer, Orry se habría opuesto a esta operación ${ }^{13}$. Aún más, llegada la iniciativa a oídos de las autoridades francesas, estas pedirían a su embajador extraordinario en Madrid, el marqués de Brancas, que, de forma prudente y diplomática, hiciese un seguimiento de la misma y tratase de que los negociantes y ministros españoles prefiriesen los barcos franceses para la Armada y comercio por encima de los de cualquier otro país. Aparte de la compra y construcción de navíos, los reunidos propondrán de cara al futuro la elaboración de un proyecto para la creación de arsenales y, finalmente, una mejora en la formación de los oficiales de la Marina española. Pero estas dos últimas propuestas, por el momento, debían esperar.

10. Ozanam, D.: «La política exterior de España en tiempo de Felipe V y Fernando VI», en Jover Zamora, J. M. a (dir.): La época de los primeros Borbones. La nueva Monarquía y su posición en Europa (1700-1759). Madrid, 1985, vol. XIX de la Historia de España R. Menéndez Pidal, pp. 457-459. Alguno adelanta la junta al año 1705. Ana Crespo, siguiendo a D. A. Perona Tomás, en lugar de una junta en 1708, concreta que se trató de una junta especial para el restablecimiento del comercio, entre 1706 y 1708, donde en realidad se expondría «un programa integrado para unificar las reformas a la Marina y el comercio colonial». En dicha junta, quedaría patente también el valor de la primera como instrumento para la defensa y el segundo, aunque reconoce que en ella se vería «que la puesta en práctica de un proyecto naval no sería posible sin medidas centralizadoras», «El comercio y la Armada de la Monarquía: la Casa de Contratación y la Intendencia General de la Marina de Cádiz, 1717-1750», Cuadernos monográficos del Instituto de Historia y Cultura Naval. La Casa de Contratación de Sevilla, aproximación a un centenario (1503-2003)», 39, 2002, p. 66.

11. Ozanam, D. y Mézin, A.: op. cit., p. 129 , nota 8.

12. Kuethe, A. J. y Serrano, J. M.: «El astillero de La Habana y Trafalgar», Revista de Indias, 241, 2007, pp. 766-767.

13. Pérez-Mallaína, P. E.: Política naval española en el Atlántico. 1700-1715. Sevilla, 1982, p. 405. 
El año 1717, cuatro después de la firma del tratado de Utrecht, será especialmente importante para la consecución de las futuras reformas. Una Real Cédula de 21 de febrero de 1714 consumaba la reagrupación de las diferentes escuadras pergeñada en 1708, creando oficialmente la Armada Real ${ }^{14}$. Poco más tarde, un Decreto de 30 de noviembre había formado un ministerio específico para la Marina, la Secretaría de Estado y del Despacho de la Marina e Indias. Este organismo, de quien llegará a depender dicha Armada, al igual que el resto de las secretarías, suponía una apuesta por la llamada «vía reservada», vinculada a lo administrativo, más eficaz para la toma de decisiones del monarca, en detrimento de la vía tradicional a través de los respectivos consejos de la Corona ${ }^{15}$. Como remate a todo ello, el 6 de junio de 1717, Patiño reunirá en un Cuerpo General el personal de la Armada Real recientemente formada, dotándole al poco de las instrucciones correspondientes ${ }^{16}$. Pero estas reformas debían complementarse según vimos con las referidas al comercio ultramarino.

\section{La irRupción de José Patiño}

Para este nuevo impulso a la Marina y el comercio, se hizo necesario la búsqueda de ministros apropiados. En ella, inicialmente, tuvo una responsabilidad importante el lobby italiano, formado en parte por antiguos servidores de la Administración española emigrados a la Península, una vez sus territorios de origen hayan pasado a dominio austriaco.

En pos del relanzamiento de la política marítima, el entonces todopoderoso cardenal Alberoni se valdría de un compatriota, el milanés José Patiño y Rosales ${ }^{17}$,

14. Quedaban fuera de ella, no obstante, la escuadra de galeras del Mediterráneo y las dos armadas americanas de Barlovento y del Mar del Sur.

15. Luis XIV habría aconsejado previamente a su nieto que no utilizase los consejos para el gobierno y prefiriese en su lugar el despacho. Ello le permitía tener, a través de sus intermediarios (así su embajador), una mayor influencia en los asuntos españoles, que con el sistema tradicional (CASTELLANO, J. L.: art. cit., pp. 137-138).

16. San Martín de Artiñano, F. J.: La defensa militar de la Carrera de Indias. La infantería de Armada y el tercio de galeones (1521-1717). Madrid, 2015, pp. 460-461. En 1717 desaparecía la Armada de la Guarda y su Tercio de Galeones. Los miembros de este último pasarían a engrosar los batallones de Marina recién creados.

17. La figura de Patiño llena una época de gran importancia para Cádiz y su bahía y las primeras reformas borbónicas. La investigación sobre su figura ha avanzado desde las obras clásicas de Rodríguez Villa, A.: Patiño y Campillo. Reseña bistórico-biográfica de estos dos ministros de Felipe $V$ formada con documentos y papeles inéditos y desconocidos en su mayor parte, por... Madrid, 1882; Salva y Riera, J.: Patiño. Madrid, 1942, y Béthencourt Massieu, A.: Patiño en la politica internacional de Felipe V. Valladolid, 1954. Nos falta todavía una buena biografía de su figura. Aparecen datos de interés, particularmente de su obra en: Pulido Bueno, 
que había llegado a España desde Italia en compañía de Felipe de Anjou en 1703, y en pocos años se convertiría en una personalidad clave para el desarrollo la política de ensamblaje entre la Marina y el comercio y, en lo que a nosotros interesa, de la asociación privilegiada a ella de Cádiz y su bahía.

Julio Alberoni había ascendido al poder tras la caída de la princesa de los Ursinos en 1714, de la mano de la nueva mujer fuerte de la Corte, Isabel de Farnesio, segunda esposa del rey, cuya boda había hecho posible, convirtiéndose un año después en ministro principal de la Corona. Su habilidad para lograrlo y su entrega a las pretensiones de la reina lograron que el Mediterráneo se convirtiera temporalmente en eje principal de la política exterior española, y que Alberoni pusiera su inteligencia y su poder al servicio de la misma, arrastrando también a José Patiño. Pero esta entrega no bastó para que descuidase del todo la política atlántica y la mejora de la Marina ya apuntada.

Antes de entrar en el círculo de Alberoni, Patiño hubo de demostrar su valía, ocupando cargos muy importantes en la todavía incipiente Monarquía borbónica. Tras ser nombrado miembro del Consejo de Órdenes Militares en 1707, apenas unos años después (1711) accederá al puesto de intendente de Extremadura y, en 1713, al de superintendente de Cataluña, participando activamente en la Nueva Planta uniformizadora que se aplicará al Principado tras la toma de Barcelona en 1714. Su tarea, delicada, consistirá en la modificación del viejo sistema fiscal de la región, y en la aplicación del llamado catastro.

Con este bagaje de experiencias político-administrativas y fiscales, y el apoyo inicial del embajador francés Amelot y del mariscal de la misma nacionalidad Tessé, favorecido este a su vez por la reina y Grimaldo, el cardenal Alberoni no tardó mucho en fijar los ojos en Patiño para hacerlo su estrecho colaborador, aunque poco después, las relaciones entre ambos se enturbiaran ${ }^{18}$.

I.: José Patiño: el inicio del gobierno político-económico ilustrado en España. Huelva, 1998, y Pérez Fernández-Turégano, C.: Patiño y las reformas de la administración en el reinado de Felipe V. Madrid, 2016.

18. Así lo expresa el propio Patiño en sus dos versiones de la «Exposición reservada», que debió de redactar por los años 20 (Cfr. RodRíguez Villa: op. cit., pp. 23-57, especialmente pp. 52-57). Patiño escribe precisamente esta «Exposición» para defenderse de los fracasos de las operaciones frustradas o irrelevantes, que el Cardenal o el rey le habían encomendado, a pesar de su punto de vista crítico hacia las mismas. Vid. asimismo Professione, A.: Il ministero in Sapagna é il proceso del Cardinale Giulio Alberoni. Turín, 1898. Según este autor, Patiño no habría estado de acuerdo con algunas de las iniciativas emprendidas por Alberoni, y este le habría tratado frecuentemente de manera displicente. Igualmente, LUZzi TrAficANTE, M.: «Los hombres del catastro y de la nueva monarquía: Patiño y Ensenada en la gestión doméstica de la Monarquía del siglo xviII», C. T. Catastro, 82, 2014, pp. 49-68.

Ediciones Universidad de Salamanca / 요 Stud. his., H. ${ }^{a}$ mod., 39, n. 2 (2017), pp. 115-152 
Así pues, tanto por mediación de Alberoni como por sus propios méritos, el rey nombrará a Patiño Intendente General de Marina, puesto recién creado ${ }^{19}$ por Real Orden de 28 enero de 1717, siguiendo el modelo francés ${ }^{20}$. Al texto, aunque conocido, no se le ha dado la relevancia requerida. En realidad, mucho más que un nombramiento, debe entenderse como producto de las reflexiones expresadas en las juntas referidas por boca de algunos ministros. Es clave para entender las prioridades establecidas al inicio de su reinado por el primer Borbón y conocer medidas importantes que se desarrollarán más tarde.

En dicha ley, además de las amplias atribuciones que se le confieren a Patiño, el rey aprovecha para anunciar varios proyectos, para los cuales, obviamente, desea contar con él. El monarca le encarga expresamente, en su calidad de Intendente, con prioridad, todo lo que concierne a la puesta a punto de los bajeles, la dotación de los equipajes en sus diferentes niveles, previo conocimiento de las disponibilidades de la zona; la vigilancia de los almacenes y de los cargamentos que vayan en los barcos, así como cuidados de tipo forestal, consistentes en la plantación de árboles para la construcción de barcos y carenas, además de la conservación de montes y plantíos a este mismo fin. Es, sin duda, la base del programa de construcción naval y de control del comercio.

Por lo que respecta a los demás proyectos a desarrollar, el monarca aprovecha el nombramiento para señalarle dos de carácter industrial vinculados ambos a la Marina, sin fijar plazo alguno para su ejecución. Se trata de la instalación de fábricas de barcos (astilleros) y de pertrechos navales: jarcia, lona, velamen y los concernientes al armamento y construcción de los navíos. En ninguno de los casos se señalan los lugares de su instalación, limitándose a indicar que habían de ser «los parajes que fueren más a propósito». Eso sí, cuidando el Intendente la proximidad de la zona de arbolado a los astilleros para que pudiera ser utilizada fácilmente.

El contenido, por lo tanto, es parte de un proyecto a largo plazo («la referida planta que quiero formar de mi Marina, y (que) se habrá de observar en mis

19. AGI [en adelante Archivo General de Indias], Contratación, 5786, L.2, F.01R-02V. Aunque las intendencias habían sido creadas apenas unos años atrás (1711), la Intendencia General de Marina no era una mera aplicación de este modelo a la Armada. Las superintendencias, existentes en España con anterioridad, también diferían del modelo aplicado a Patiño. El cargo de intendente General de Marina se puede considerar de nuevo cuño, aunque Francisco de Varas y Valdés, antecesor de Patiño en el puesto, fuese el primero en ocuparlo. (Crespo Solana, A.: «El comercio y la Armada de la Monarquía», pp. 70-71). Vid. también Pando Villarroya, J. L.: La Intendencia de la Armada. Madrid, 1982, y, sobre todo, Crespo Solana, A.: La Casa de Contratación y la Intendencia General de la Marina en Cádiz (1717-1730). Cádiz, Universidad, 1996.

20. Vid. Cosandey, F.: Monarchies espagnole et française: 1550-1714. París, Atlande, 2001.

Ediciones Universidad de Salamanca / 요 Stud. his., H. ${ }^{a}$ mod., 39, n. 2 (2017), pp. 115-152 
reinos»), que, como se ha dicho, el rey vincula en su Real Orden a la figura de José Patiño, convirtiéndole en su factótum.

A continuación el monarca relaciona su propósito de nueva planta para la Marina con el comercio, según venía insistiéndose desde años atrás. Pero lo hace, conviene resaltarlo, colocando Cádiz en el centro de la misma: «se hace preciso [se dice en el texto del Decreto] que toda la atención y cuidado se haya de poner en el puerto de Cádiz». En consonancia con ello, le ordena pasar «a residir y exercer vuestro empleo en dicha ciudad de Cádiz», por ser en dicho lugar «donde se han de aprestar y despachar las flotas, galeones y escuadras [es decir, la parte comercial y la militar], según convenga a mi Real servicio».

Pero Cádiz, como sabemos, venía ejerciendo desde 1679 el papel de cabecera del monopolio comercial español con las Indias. Lo novedoso era que el monarca consideraba ahora preciso reforzar esta función transfiriéndole desde Sevilla la institución que lo regulaba, es decir, la Casa de la Contratación. Así, el rey, en el mismo texto de nombramiento de Patiño, se anticipará a su Real Orden de 12 de mayo, en la que se ratificaba dicho traslado, añadiéndole asimismo el del Consulado.

Desde Cádiz, el Intendente debería «velar sobre el comercio», sumando dos tareas fundamentales: proponer al rey medidas para su aumento y «desterrar los abusos», existentes o por venir, que afecten a los intereses de la Corona (es decir, los impuestos) y del público.

Sin embargo, el cargo de Intendente General de Marina aparecía en la Real Orden fundamentalmente vinculado a la Armada. Era necesario acompañarlo de otro cargo vinculado estrechamente al comercio hispanoamericano que se deseaba mejorar. Así, en ella se disponía a la vez que Patiño presidiera el Tribunal de la Casa de la Contratación. Se apuntaba incluso allí la reforma de la institución («en el número y forma que se os prescribiere»). Y no solo eso, preludiando el ya próximo traslado del Consulado a la bahía, se ordenaba que los diputados del mismo residieran en Cádiz,

para que así este [el Consulado] como el Tribunal de la Contratación puedan ocurrir con más facilidad y prontitud a las providencias de los que, arribando a Cádiz, deberán seguir sus dependencias ante el juzgado de ellos.

Finalmente, el monarca otorgaba a Patiño un tercer nombramiento: Superintendente del Reino de Sevilla, a imitación del modelo de «las superintendencias particulares de las tropas que se hallaren en él», precedentes de las intendencias. Significaba la otra cara de la reforma, ligada al tema siempre acuciante para el Estado de los impuestos, en este caso, obviamente, relacionados con el comercio, pues se trataba de «las rentas, derechos y Reales intereses que en los navíos de venida de flotas me pertenecen, o en cualquiera otra forma me pudieran pertenecer».

Ediciones Universidad de Salamanca / 요 Stud. his., H. ${ }^{a}$ mod., 39, n. 2 (2017), pp. 115-152 
La Real Orden concluía ofreciendo a Patiño la potestad de nombrar subdelegados (sic) para la ejecución de las tareas que le habían sido encomendadas, previa aprobación de la Corona. En resarcimiento de todos sus trabajos se establecía su sueldo en 12.000 escudos de vellón anuales.

Antes de tomar posesión de los referidos cargos, residente aún en Cataluña, Patiño, sin saber el motivo según él mismo declara, fue llamado a Madrid. En la capital, por enero de 1717 o, quizás mejor, a finales del año anterior, se le informaría sin duda de los nombramientos que se preparaban para él, invitándole al mismo tiempo a participar en varias juntas, en presencia de Alberoni. Al parecer fue el almirante Andrés de $\mathrm{Pez}^{21}$ quien, a instancias de la Corona (Patiño no lo asegura), había tomado dicha iniciativa.

El propio Patiño resumirá en su «Exposición Reservada» más tarde los contenidos de las sesiones, «que hallé resueltos»: impuestos a pagar en España y América por las mercancías y los metales preciosos, reglas para la recluta de marineros y apresto de barcos, «introducción y educación de guardias marinas», regularización del despacho de flotas y galeones (afectados sin duda por los desajustes de la pasada guerra), establecimiento del estanco de tabacos de La Habana y navíos que habían de destinarse a ello, y como de rondón, a pesar de su innegable importancia, el traslado de la Casa de la Contratación desde Sevilla a Cádiz, como la Real Orden de 28 de enero analizada anteriormente terminaría certificando.

Sin embargo, encargo de Alberoni «con gran particularidad», el asunto que más distracción suscitará ahora en Patiño, forjando su retiro temporal de las tareas fundamentales asignadas inicialmente, será el mandato para que formase una escuadra de 12 navíos con vistas a operar en el Mediterráneo, que se pondrían a disposición del Papa para combatir a los turcos ${ }^{22}$. No debemos olvidar que, paralelamente, se habían puesto en marcha las negociaciones del Concordato con la Santa Sede, en las que Alberoni, pretendiente asimismo al capelo cardenalicio, tuvo un importante pape ${ }^{23}$. Para la aplicación de esta política, Patiño será llamado a la Corte y luego enviado a Barcelona varias veces, de donde había de partir la

21. A Andrés de Pez se le puede considerar como el contrapunto de López Pintado, almirante sevillano y sevillista en cuanto a la defensa que llevará a cabo de los derechos de su ciudad a residenciar la Contratación y el Consulado, es para Adolfo de Castro el responsable del traslado (Vida del Almirante D. Andrés de Pes, Ministro de Marina. Cádiz, 1879, p. 94). Sobre el almirante López Pintado, la reciente obra de Tapias Herrero, E.: El almirante López Pintado (1677-1745). Sevilla, 2017.

22. Todo ello lo resume Patiño en su ya referida «Exposición Reservada», que Antonio Rodríguez Villa incorpora (op. cit., p. 23).

23. Barrio Gozalo, M.: «El cardenal Alberoni y España. Política religiosa y carrera eclesiástica», Hispania Sacra, LXIII:1278, 2011, pp. 218-222.

Ediciones Universidad de Salamanca / 요 Stud. his., H. ${ }^{a}$ mod., 39, n. 2 (2017), pp. 115-152 
escuadra previamente constituida en Cádiz bajo el control de Francisco de Varas, a quien el Intendente había nombrado su asesor. Esto no era sino el inicio de la política mediterránea arriba referida ${ }^{24}$.

Más tarde se ocupará a Patiño igualmente de las expediciones con destino a Cerdeña y Sicilia, a pesar de las notables deficiencias de todo tipo observadas (barcos y marinos inapropiados, falta de pertrechos y carenado, etc.), no obstante dedicarles recursos vinculados al comercio hispanoamericano. Y más tarde se ocupará en Cádiz de la frustrada flota contra Inglaterra y de las operaciones en el Norte de África, especialmente en Ceuta. Unas y otras al parecer fueron desaconsejadas por Patiño. En algunas de las expediciones, incluso, se verá obligado Patiño a embarcar ${ }^{25}$.

¿Por qué se le desviará tan pronto, entre 1717 y 1720 aproximadamente, de las que parecían las reformas más importantes que debía acometer, relacionadas con el comercio hispanoamericano y los nombramientos recibidos? Sin embargo, aunque Alberoni fuese en última instancia responsable del desvío, los encargos recibidos por el Intendente entraban también dentro del cargo que le había asignado, que abarcaba no solo el Atlántico, sino también el Mediterráneo (el «resguardo de mis dilatadas costas marítimas en el Océano y Mediterráneo», había establecido el rey en el texto de enero de 1717). La política del Gobierno propiciaba en esos momentos el predominio del segundo, y Alberoni, puestos los ojos en su país de origen, queriendo sacar provecho y contentar a la reina, se convirtió en factor decisivo de dicha política ${ }^{26}$. De ahí que quisiera apoyarse en su antiguo protegido, el ya experimentado en otras lides bélicas José Patiño.

Pero tampoco debemos rechazar lo que el propio Intendente también nos recuerda: que de la colaboración amistosa entre él y el cardenal se había pasado a los celos y la envidia del segundo hacia Patiño (Alberoni le habría puesto varias veces trabas para visitar al rey). Sin olvidar asimismo la intervención de terceros, deseosos de sustraer a Patiño de su cometido americanista. Así lo expresa él mismo, bien es verdad que sin demasiadas aclaraciones, cuando culpabiliza de apartarle de la Corte a sus enemigos y a «los contrabandistas de diferentes naciones extranjeras [¿tal vez, por el temor de que Patiño, más independiente y dotado de grandes

24. Según Manuel Ravina, en estas reuniones se habría producido incluso un reparto de cargos: Alberoni pasaría a ocupar el más alto, Secretario del Despacho Universal; Pez el de Gobernador del Consejo de Indias y Patiño el de Intendente General de Marina con destino en Cádiz.

25. «Exposición», pp. 37-57.

26. Alonso Aguilera, M. A.: La conquista y el dominio español de Cerdeña 1717-1720: introducción a la política española en el Mediterráneo posterior a la Paz de Utrecht. Valladolid, 1977.

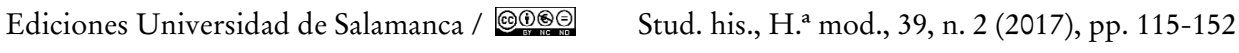


MANUEL BUSTOS RODRÍGUEZ

EL TRASLADO DE LA CASA DE LA CONTRATACIÓN Y DEL CONSULADO DE INDIAS Y SUS EFECTOS

EN EL CONTEXTO DE LA NUEVA PLANTA DE LA MARINA Y DEL COMERCIO AMERICANO

poderes, fuese más estricto en la persecución del fraude?], que, por disponer por mí la execución de las órdenes del rey para la América, ya me culpaban de enemigo irreconciliable de ellos» ${ }^{27}$. De hecho, Patiño llegaría a solicitar en varias ocasiones que le retirasen de los compromisos que le habían echado encima.

\section{El desarrollo de la nueva Planta de la Marina y del comercio ameri- CANO POR PATIÑO}

El camino que conduce hasta el traslado no está aún satisfactoriamente reconstruido, ya que, probablemente, una parte importante de las decisiones y, sobre todo, de las presiones ejercidas y de los acuerdos privados se produjeron verbalmente o en secreto, sin dejar huella documental. Por otro lado, faltan aún por exhumar de los archivos misivas y escritos de los principales protagonistas del evento, susceptibles de dar cuenta acerca de los argumentos utilizados y de las responsabilidades del cambio. No podemos olvidar que la decisión del traslado, al margen del secreto impuesto, no debió desde el principio de estar falto de controversia, de posiciones a favor y en contra, de la participación de diferentes instancias y agentes que oscurecen y complejizan el proceso.

En principio, al almirante gaditano Andrés de Pez o Pes, Gobernador del Consejo de Indias desde enero de 1717 y otra de las personalidades interesadas en dicho cambio, a quien se dirigirá la orden del traslado, se le atribuye ser el artífice de la inclusión de la Casa en la Real Orden de 28 de enero y desear que fuese Patiño quien liderara el proceso de transferencia ${ }^{28}$. Así, el binomio formado por Pez y Patiño estará presente en el arranque de la operación ${ }^{29}$, si bien no sabemos de quién habría partido en última instancia la idea. Ana Crespo afirma que los comerciantes de Cádiz atribuyeron el traslado a una decisión de Andrés de Pez, en tanto otros lo vincularon a un grupo más amplio, donde estarían, además del almirante, Francisco de Varas y Valdés, respaldado por comerciantes extranjeros ${ }^{30}$.

27. «Exposición», p. 46.

28. Walker, G. J.: Política española y comercio colonial: 1700-1789. Barcelona, 1979, p. 128. Para Adolfo de Castro el responsable del traslado es Pez (Vida del almirante D. Andrés de Pes. Cádiz, 1879, p. 94). En un informe detallado, Pez o Pes había manifestado las dificultades para la navegación a través del Guadalquivir, así como la conveniencia de que los dos tribunales fuesen instalados en la bahía de Cádiz.

29. Vid. Crespo Solana, A.: «La acción de José Patiño en Cádiz y los proyectos navales de la Corona del siglo xvinI», Trocadero: Revista de Historia Moderna y Contemporánea, 6-7, 1994-1995, pp. 35-50.

30. Idem, p. 108. Ildefonso Pulido amplia la paternidad del traslado, abriéndolo a «un grupo de hombres gaditanos» de varios oficios (cita en concreto a Pez y Francisco de Varas), respaldados por comerciantes extranjeros (op. cit., p. 177).

Ediciones Universidad de Salamanca / 요 Stud. his., H. ${ }^{a}$ mod., 39, n. 2 (2017), pp. 115-152 
Para Manuel Ravina la idea del traslado se habría fraguado en una reunión en la que participaron Alberoni, José Patiño y el almirante Andrés de Pez. Según este autor, ni cortos ni perezosos, los tres habrían decidido a tal fin repartirse los cargos que deberían hacerlo posible, como en realidad se hizo: Alberoni pasaría a ocupar el más alto, el de Secretario del Despacho Universal; Pez sería Gobernador del Consejo de Indias y Patiño Intendente General de Marina con destino en Cádiz ${ }^{31}$.

Mientras, a lo largo del año 1717, la inquietud iba cundiendo en Sevilla. En la ciudad se rumoreaba que no tardaría en hacerse efectivo el traslado; pero la responsabilidad inicial no se le atribuía al rey ni a ninguno de los ministros en particular, sino a las gestiones de «algunos individuos de Cádiz» para sacar adelante el pretendido traslado ${ }^{32}$. Se trataría de una especie de "conspiración» contra la ciudad que había residenciado la sede de la Casa desde su constitución en 1503.

A pesar de dichos temores, con su nombramiento recién obtenido, José Patiño se trasladaría a Cádiz, siguiendo la orden recibida en el decreto de su nombramiento como Intendente. Aquí llegará el 11 de febrero, apenas transcurridas dos semanas de su publicación ${ }^{33}$. En contraste con Sevilla, en la ciudad, representada por su ayuntamiento, se le dispensó una espléndida acogida, y la acción se repetiría cada vez que regresaba de alguno de sus viajes, bastante frecuentes por otro lado en esta primera época. Además de su brillante hoja de servicios a la Corona ya analizada, Patiño poseía viejos vínculos con algunas personalidades gaditanas. Una vez en la ciudad constataría lo que, al parecer, el almirante Pez, buen conocedor de Cádiz, ya le había expresado: «que no hallaría [aquí] exposición alguna para apresto de navíos, pues no había ni siquiera un paraje donde se pudiera cocer un caldero de brea» ${ }^{34}$, aludiendo sin duda a la falta de una mínima infraestructura para la construcción de los navíos.

El cabildo municipal hispalense, sabedor del contenido del decreto de nombramiento, se apresuró a enviar un memorial al rey, fechado el 13 de febrero, saliendo al paso de las noticias que le llegaban ${ }^{35}$. Como medida compensatoria, una Real Cédula de 8 de mayo de 1717 creaba en Sevilla una Diputación del comercio o

31. Crespo, A.: «El comercio y la Armada de la Monarquía», pp. 70-71.

32. Ravina Martín, M. (ed. y estudio preliminar): El pleito Cádiz Sevilla por la Casa de la Contratación. Memorial de Frco. Manuel Herrera 1726. Cádiz, 1984, p. 60.

33. Ildefonso Pulido retrasa esta entrada hasta el día 17, pero ello no se ajusta a lo que el mismo Patiño expresa.

34. «Exposición», pp. 25-26.

35. Archivo Municipal de Sevilla [en adelante AMS], Papeles del conde de Mejorada, vol. II, 1700-1724, n. ${ }^{\circ} 19$. 
tribunal de justicia para asuntos del comercio hispanoamericano, con dos diputados al frente, pero con jurisdicción restringida al ámbito local ${ }^{36}$.

Mientras tanto, Patiño había comenzado a poner manos a la obra, nombrando como colaboradores suyos a dos personas expertas: Miguel de Zabala y Auñón, regidor en el cabildo municipal de Badajoz y, más tarde, Superintendente General adscrito al Erario (Pagaduría de juros y mercedes), para los asuntos que Patiño había dejado pendientes en Cataluña, y el principal, Francisco de Varas y Valdés, su antecesor en la Intendencia, experto en cuestiones de Marina, para tratar de las relativas al ámbito andaluz.

Sus actuaciones comenzarían muy pronto, pues entre marzo y mayo de 1717, pudo ya informar a Alberoni que había establecido «la compañía de guardias marinas, compuesta de toda la nobleza de España», según se había anunciado en las juntas madrileñas a las que acudiera en su día Patiño ${ }^{37}$.

El 12 de mayo de 1717, finalmente, se publicaba en San Ildefonso de La Granja la Real Orden que iba a consolidar el importante papel asignado a Cádiz en el comercio con América y completaba la reforma mancomunada con la Armada. Ampliación de la publicada el 28 de enero, en ella se hacía firme la orden de traslado de la Casa de la Contratación a Cádiz, que en aquella se había anticipado, incluyendo además en la misma a la otra gran institución de la Carrera: el Consulado de Cargadores a Indias, residenciado desde 1543 en Sevilla. Venía a justificarse esta acción en la necesidad de que las instituciones del comercio estuviesen junto a la cabecera del monopolio, que ya, desde 1679, se hallaba en la bahía. Aunque la decisión correspondiera, pues, a Felipe V, la decisión de incluir también el Consulado, según se ha apuntado, debía venir fraguándose de antes en los mentideros políticos cortesanos.

El documento de mayo incidía a la vez en la necesidad de reforma del Tribunal de la Casa de la Contratación, ya apuntada en la Real Orden de nombramiento de Patiño de enero («el cual deberéis establecer en el número y forma que se os prescribiere...»). Sin embargo, ese «prescribiere» quedaba en realidad en manos de José Patiño. ¿En qué sentido orientaría el Intendente dicha reforma? Sin duda, en el que estratégicamente se había marcado el propio rey como objetivo en el documento de enero: la unión del comercio y la Armada convergentes a su vez en Cádiz y su bahía. Y a esta labor se entregó Patiño con presteza.

36. Representación de la muy Noble y muy Leal ciudad de Cadiz haze al Rey Nuestro Señor. Sobre las pretensiones deducidas por la muy Noble, y muy Leal Ciudad de Sevilla..., en Ravina, M.: op. cit., p. 78.

37. «Exposición», p. 24. 
De forma que, como se le había indicado, optó por reformar la Contratación, pero en beneficio de la Intendencia General, es decir, de un mayor control del comercio por parte de esta última. Al mismo tiempo anulaba prácticamente la presión que pudiera ejercer la Casa en contra del traslado, quedando en última instancia la protesta en manos de la Diputación del Consulado de Sevilla y, sobre todo, del cabildo municipal hispalense, en particular de algunos miembros significativos del Consulado que compaginaban su cargo con el de regidores ${ }^{38}$.

De las dos salas que tradicionalmente poseía el Tribunal de la Casa, Justicia y Gobierno, solo permaneció la primera; es decir, la que entendía en todos los asuntos de carácter jurídico, además de:

disponer el beneficio de la plata, y oro en pasta, Perlas, Esmeraldas, y demás géneros que se traen de la Real Hazienda, y Bolsas Fiscales (...) y expedir los despachos regulares para los aviamientos, viáticos, y entretenimientos de los Religiosos, que a costa de mi Real Hazienda passan a Indias ${ }^{39}$.

En cambio, la función desempeñada por la Sala de Gobierno quedaba incorporada a la Intendencia, cuyo poder quedaba así reforzado. Paralelamente se procedería a reducir el personal de la Casa. No contento con ello, Patiño introducirá en la Contratación a hombres experimentados y de su confianza: Francisco Manuel de Herrera, José Campillo, Rubalcaba, Francisco Zenón y Somodevilla, futuro marqués de la Ensenada y otros, todos llamados a desempeñar un importante papel en la futura política reformista.

Con Herrera, Patiño estrechaba sus relaciones con la ciudad de Cádiz, sede de la Intendencia y de las instituciones del comercio. Era un hombre con formación y posición dentro del ayuntamiento gaditano, del que sería su Alcalde Mayor al llegar Patiño a la ciudad. Este lo agregará enseguida a su equipo, abandonando así el cargo municipal que desempeñaba. Perseverará junto al milanés hasta la muerte de este, asesorándole en temas relacionados con la Intendencia. Patiño se lo llevará a Madrid durante algún tiempo, iniciando allí una provechosa carrera a través de una influyente red de contactos, que llegarán hasta el mismo rey, y

38. Navarro García, L.: «La Casa de la Contratación en Cádiz», en La burguesía mercantil gaditana (1650-1868). Actas del XXXI Congreso luso-español para el progreso de las ciencias. Cádiz, 1976, p. 43, y Heredia Herrera, A.: Sevilla y los hombres del Comercio (1700-1800). Sevilla, 1989, 78 y sigs.

39. «Decreto de Su Magestad de 12 de mayo de 1717. Dirigido al Consejo de Indias, mandando que el Consulado, y Casa de Contratación, que estaban en Sevilla, passen a Cádiz; y declarando al mismo tiempo los ministros, y demás personas de que se han de componer cada uno de estos Tribunales, y dependencias en que han de entender, como también las que se han de dirigir por el Intendente General de la Marina», fol. 2.

Ediciones Universidad de Salamanca / 요 Stud. his., H. ${ }^{a}$ mod., 39, n. 2 (2017), pp. 115-152 
asumiendo la peliaguda defensa de Cádiz frente a las pretensiones de Sevilla de retornar la Casa y el Consulado a la ciudad.

Por lo que respecta a José Campillo y Cossío, estará llamado también a una brillante carrera. En 1717, Patiño lo incorpora al Ministerio de Marina como oficial en el cuerpo de contadores. A partir de los años veinte irá pasando por diversos cargos de responsabilidad: en los astilleros de Guarnizo (Santander), donde sustituye a Gaztañeta como Superintendente, y de Cantabria en general ${ }^{40}$; como intendente en Zaragoza, Aragón y el Ejército, hasta llegar a principios de los cuarenta a acumular bajo su gobierno las Secretarías de Estado de Hacienda, Marina, Guerra e Indias.

En cuanto a Sebastián Lasquetti, un hombre de negocios de origen genovés asentado en Cádiz, amigo íntimo de Campillo y padrino del primer hijo de Herrera, servirá de puente entre los dos, o lo que es igual, entre los prohombres del nuevo equipo y la ciudad ${ }^{41}$.

Por último, es posible que Francisco Zenón, todavía joven, trabajase durante algún tiempo en Cádiz, al servicio de alguna compañía de comercio, aunque este dato no es del todo seguro. Llamado también, como Patiño y Campillo, a ocupar grandes cargos y empresas, servirá a este, quien propiciará junto a Patiño su encumbramiento, hasta el punto de poderle sustituir después en los cargos ministeriales.

Para impulsar la política de construcción naval, que formaba parte del proyecto global de Patiño, se optaría a la vez por un hombre avezado en estas tareas, Antonio de Gaztañeta, estrecho colaborador del propio Patiño y, probablemente, la máxima autoridad española de su tiempo en construcción naval ${ }^{42}$. Al recaer el control de las principales instituciones relacionadas con el comercio hispanoamericano y la Armada en manos de quienes eran favorables a la causa de Cádiz, quedaban fuera sus contradictores.

Pero mientras Patiño debió ocuparse de los problemas del Mediterráneo, en la bahía se hizo sentir ocasionalmente su ausencia. Él mismo reconoce que había recibido cartas «de algunos sujetos celosos de Cádiz [...] en que me explicaban, con sumo dolor, los grandes perjuicios que en mi ausencia de España se habían ocasionado al comercio». La causa, al parecer, había sido la ruptura temporal del sistema de flotas, por medio del envío de navíos sueltos a Indias «y otros puntos».

40. Castanedo Galán, J. M.: Guarnizo, un astillero de la Corona. Madrid, Ed. Naval, 1993, pp. 99, 100 y 105.

41. Rodríguez Villa, A.: op. cit., p.132, y Ravina, M.: op. cit., p. 20.

42. Ravina, M.: op. cit., pp. 66-67. 
Y también el Consejo de Indias, celoso probablemente de las atribuciones concedidas a la Intendencia General, aprovecharía la ausencia de Patiño para tomar varias medidas con las que este no estaba de acuerdo. Como él mismo se encargará de recordar: el rey le había fijado «la delicada dirección de el comercio de Indias ${ }^{43}$. Y consideraba «los asuntos de marina, comercio, tropas y hacienda y justicia [...] los más conformes al servicio de Dios y del Rey, [y así] me confirmo siempre en ellos».

Tras caer en desgracia Alberoni en 1719 por sus poco exitosas campañas del Mediterráneo, con las interrupciones descritas, se abría para Patiño una nueva etapa, en la que podía confirmar su vocación por los temas que más le incumbían. $\mathrm{Y}$ así fue, en efecto, aunque tuviera que ocuparse paralelamente de las tensiones surgidas entre Sevilla y Cádiz apenas promulgado el decreto de traslado.

En cualquier caso, con independencia de los nombramientos y de los avatares que hemos descrito, Cádiz y su bahía quedaron convertidos por ley en plataforma de las futuras reformas y eje de la nueva política naval y comercial de los Borbones. Desde entonces, con sus baches ineludibles, este conjunto, terrestre y portuario a la vez, no cesaría de crecer en todos los sentidos. Pero, ¿por qué las autoridades habían elegido la bahía de Cádiz? ¿Se trataba de una mera «conspiración» en contra de los intereses sevillanos?

\section{LA CONVENIENCIA DE LA BAHÍA DE CÁdIZ}

Obviamente, para la elección de la bahía existía un factor de peso, ya manifiesto en la Orden de traslado: aproximar el Tribunal de la Casa de la Contratación a donde estaban los comerciantes (el Consulado, su órgano de representación, también se trasladaba a Cádiz), pues era a ellos a quienes incumbía ${ }^{44}$.

Ya vimos el interés por la ciudad y su bahía de algunos ministros de los sucesivos equipos de Gobierno, bien por mantener vínculos con las fuerzas vivas de Cádiz o mirando por la mayor eficacia de las reformas proyectadas. Resultó pues fundamental la conjunción de esa serie de personalidades para llegar al traslado. De hecho, cuando alguno de estos hombres cayó temporalmente en desgracia o no encontraron quien continuara el proyecto, aquel se resintió e, incluso, estuvo a punto de fracasar. Así, en 1720, coincidiendo con una pérdida temporal de poder del Intendente, o en 1723 cuando el rey decida la reversión del traslado. Por el contrario, cuando las personas favorables a la causa gaditana volvieron a ocupar cargos importantes, esta volvería a cobrar impulso.

43. «Exposición», pp. 44-45.

44. «Decreto de Su Magestad de 12 de mayo de 1717», fols. 2-3.

Ediciones Universidad de Salamanca / 요 Stud. his., H. ${ }^{a}$ mod., 39, n. 2 (2017), pp. 115-152 
No debe olvidarse tampoco que Cádiz, durante la Guerra de Sucesión, se había convertido en un firme apoyo de la causa borbónica. Su contribución a la misma fue incesante: recluta de tropas y gastos de manutención de las mismas, formación de un regimiento de 500 hombres, donativos varios (uno, en 1706, gracioso, entre los vecinos, en proporción a sus caudales; otro también gratuito, encargado al obispo en 1707), préstamos y empréstitos, mediante empeño de una parte de sus rentas, la prórroga de los arrendamientos, el empeño de oficios municipales, el recurso a propios y arbitrios, el gravamen de impuestos o el recurso al dinero de los particulares, incluida la Iglesia. Además de pagar débitos de deudas anteriores contraídas con la Corona reclamados por esta. La mayoría de las veces no cubrirán lo solicitado, aunque a la ciudad le supusiese mucho contraer una copiosísima deuda ${ }^{45}$.

Más difícil de precisar resulta el papel de los propios comerciantes españoles, integrados en parte en el Consulado y asentados en Cádiz, en la decisión del traslado. En principio, no parece que estos ejercieran una crítica significativa ni participaran activamente en la polémica, a diferencia de los miembros de la cúpula consular (Prior y cónsules), estrechamente vinculados al cabildo municipal hispalense. En cualquier caso, lo fundamental de la pugna se dirimiría entre las representaciones municipales de ambas ciudades afectadas. Pero si la cabecera del comercio estaba en Cádiz en 1679 y una parte importante de los comerciantes venía emigrando aquí desde antes, incluidos residentes en Sevilla, poco podía afectarles el traslado de las instituciones del comercio ${ }^{46}$. Por otro lado, muchos cargadores sevillanos continuaron viviendo en su ciudad, no obstante de aumentar paralelamente el número de matriculados avecindados en Cádiz. Un punto de fuerza para la permanencia en Sevilla era la condición de cargadores de la mayoría de los matriculados en esta ciudad, mientras que los comerciantes al por mayor, que solían identificarse frecuentemente con los extranjeros, base fundamental de la actividad gaditana, no llegaban a adquirir un peso similar en la ciudad hispalense ${ }^{47}$.

45. Benítez Barea, A.: «El impacto de la Guerra de Sucesión en Cádiz, Felipe V de Borbón (1701-1746)», en Pereira, J. L. (coord.): Felipe V de Borbón 1701-1746, pp. 481 y sigs. Bustos RodríGuez, M.: «La ciudad de Cádiz y su contribución a la Guerra de Sucesión, 1704-1705», Anales de la Universidad de Cádiz, 1, 1984, pp. 139-148.

46. Bustos Rodríguez, M.: «De Sevilla a Cádiz: hacia el cambio de funcionalidad en el seno del monopolio andaluz con América». Estudios de la Universidad de Cádiz ofrecidos a la memoria del profesor Braulio Justel Calabozo, 1998, pp. 487-498.

47. Heredia Herrera, A.: Élite y poder: comerciantes sevillanos y asociaciones mercantiles en el siglo XviII», Archivo Hispalense: Revista histórica, literaria y artística, 70:213, 1987, pp. 79-80.

Ediciones Universidad de Salamanca / 요 Stud. his., H. ${ }^{a}$ mod., 39, n. 2 (2017), pp. 115-152 
Muy diferente debió suceder entre los comerciantes extranjeros asentados en Cádiz, en particular los franceses, habituados a dirigir sus negocios desde Cádiz, bien de manera directa, bien como colaboradores de los comerciantes españoles o, sencillamente, mediante la práctica del fraude, aprovechando la facilidad que a este ofrecía el amplio espacio de la bahía. La alusión de Patiño en su «Exposición» a «los contrabandistas de diferentes naciones extranjeras» parece referirse a este problema ${ }^{48}$.

En realidad, desde la presencia, a partir de 1663, de Francisco Báez Eminente y sus sucesores al frente de la aduana de Cádiz, favoreciendo claramente el envío de las mercancías extranjeras por la reducción de gravámenes, los extranjeros se sentían atraídos por la ciudad, en detrimento del puerto de Sevilla, cuyos aranceles resultaban mucho más altos ${ }^{49}$.

Tampoco deben olvidarse los factores de carácter geográfico-estratégico arriba referidos; es decir, el papel de Cádiz como paso obligado entre el Mediterráneo y el Atlántico, ahora reforzado por la presencia británica en Gibraltar y Menorca y la ofensiva española en el Mediterráneo; pero también a la amplitud de la bahía gaditana, cuyo valor de reclamo se había ido progresivamente fortaleciendo, toda vez que los barcos, cada vez de mayor tonelaje y complejidad (sobre todo tras las transformaciones técnicas introducidas en los navíos en el último tercio del siglo XVII ${ }^{50}$, debían sortear toda clase de riesgos a la hora de surcar el Guadalquivir y la peligrosa barra de Sanlúcar, con el correspondiente incremento de los costes de transporte.

En contraposición, la bahía poseía tres entradas que iban progresivamente estrechándose, hasta convertirse en un auténtico abrigo para las naos; así, los aproximadamente $10 \mathrm{~km}$ de anchura existentes en la boca de acceso entre Cádiz y Rota, se reducían a la mitad entre el castillo de Santa Catalina en El Puerto y la ciudad y, finalmente, a algo menos de $2 \mathrm{~km}$ entre los castillos de El Puntal y Matagorda. Contaba además con varios caños de drenaje, permitiendo la salida de pequeñas embarcaciones hacia alta mar sin hacer el recorrido de la bahía.

48. «Exposición», p. 46.

49. Para la labor de Francisco Báez Eminente y sus sucesores en la aduana, vid. Bustos Rodríguez, M.: Nueva Historia de Cádiz vol. III Época Moderna. Un emporio atlántico en Europa. Madrid, 2014, pp. 87-90.

50. Vid. Serrano Mangas, F.: Los galeones de la Carrera de Indias, 1650-1700. Sevilla, 1986, pp. 98 y ss. y Pérez-Mallaina, P. E.: op. cit., p. 29. Un resumen del tema en Apestegui Cardenal, C.: «Arquitectura y construcción navales en la España Atlántica, el siglo xviI y primera mitad del xviII. Una nueva sistematización», Proceedings. International Symposium on Archeology of Medieval and Modern Ships of Iberian Atlantic Tradition. Consultado en http:// www.patrimoniocultural.pt/media/uploads/trabalhosdearqueologia/18/16.pdf, 16.1.2017, pp. 163-212.

Ediciones Universidad de Salamanca / 뾰 Stud. his., H. ${ }^{a}$ mod., 39, n. 2 (2017), pp. 115-152 
Cádiz poseía además en su entorno ciudades importes, como El Puerto, Jerez o Chiclana, y un campo cercano feraz para el abastecimiento de los habitantes y de los barcos, sin olvidar la abundancia de sal con vistas a la conservación de los productos consumidos por las tripulaciones. Podía jugar en contra, aunque rara vez fuese criticado (antes bien, se consideraba un elemento beneficioso para la defensa), la presencia de una amplia zona pantanosa alrededor y, sobre todo, las deficiencias del puerto gaditano.

Antes de las reformas, se venían utilizando tres zonas a manera de puerto: el principal, junto a la plaza de la Corredera, hoy de San Juan de Dios; la de Puntales, donde podían cargarse y descargarse mercancías, carenarse los barcos y existía un pequeño astillero. Por último, el fondo de la bahía, que las naos podían utilizar como resguardo, invernada o carena, cerca de La Carraca, en la Isla de León. Aquí se operaría una de las acciones más importantes del proyecto borbónico encomendado a Patiño: la construcción del arsenal del mismo nombre ${ }^{51}$.

El ingeniero Antonio Salas escribirá en 1735 que la idea que había guiado inicialmente este proyecto había sido la de «poner todo lo que necesita un arsenal completo de Marina, en un mismo sitio, seguro, que su entrada fuera impracticable por tierra y no muy fácil por mar, por cuya razón se superaron las grandes dificultades que se ofrecieron para los fundamentos, terraplenes y transporte de los materiales para los edificios que se han construido y se construyen en La Carraca ${ }^{52}$.

Con todo, era necesario acometer obras de adaptación en los puertos, donde apenas existían muelles. Los proyectos de finales del siglo XviI no se habían ejecutado. Ahora, forzados por la centralidad asignada por el rey y sus ministros a la bahía se acometerá la prolongación hacia el mar de los dos muelles que cerraban el puerto principal por ambos lados: el de San Felipe, junto al baluarte del mismo nombre, y el de Puerta del Mar. Ello permitiría proteger los navíos de los fuertes vientos de Levante y Poniente que solían afectar a la zona ${ }^{53}$.

La bahía poseía también una cierta tradición industrial, aunque incipiente, vinculada a los barcos. Así, la construcción en Puntales de algunos navíos de escaso tonelaje. O la carena en el Real Carenero de la Isla de León, que iniciara

51. La isla de Trocadero también se utilizaba en menor escala, aunque acrecentando su protagonismo en el Setecientos, para refugio de barcos de la Armada, almacenaje de pertrechos y algunas operaciones de carenado. Al cabo del tiempo se había pensado en ella como base para un astillero, pero la idea no tomó cuerpo del todo hasta mediados de la centuria (Vid. IgLesias Rodríguez, J. J.: «El "Canal Prodigioso": el caño del Trocadero en el siglo xviII», Revista de Estudios Puertorrealeños, 1, 2015.

52. Cit. por Quintero González, J.: Jarcias y lonas. La renovación de la Armada en la babía de Cádiz 1717-1777. Cádiz, Publicaciones del Sur, 2003, p. 133.

53. Vid. AHMC, cajón 1, n. ${ }^{\circ}$ 166, 168 y 202, sigs. 5.3, 5.6 y 5.7. 
su marcha probablemente a principios del siglo XVII, y alcanzaría por los años del traslado un significativo desarrollo. Desde finales del Seiscientos, consta también la existencia de almacenes de lonas para el velamen de los barcos, sin que deba descartarse su posterior fabricación, aunque a pequeña escala. No lejos de allí, en Puerto Real, se hacían jarcias, si bien la producción resultaba a todas luces insuficiente para los proyectos de Patiño.

Un aspecto importante a considerar fue el sistema defensivo de la bahía. Alrededor de ella misma habían ido surgiendo en diferentes épocas castillos y baterías. Opuestos entre sí, en la parte ancha de la misma, a principios del XVIII se situaban sendos castillos de Santa Catalina, uno en Cádiz y otro en El Puerto. A continuación, el de San Lorenzo del Puntal de la ciudad se oponía al de Matagorda en Puerto Real y cerca de este, en la isleta del Trocadero, surgiría el de San Luis. La zona litoral entre Cádiz y la Isla de León aprovechaba las torres vigía que, desde mucho tiempo atrás, se habían venido instalando por la costa. Por último, el frente de tierra contaba con las fortificaciones del Puente Zuazo en la Isla de León, junto al caño de Sancti Petri, y las de Puertas de Tierra a la entrada de Cádiz. Estas últimas se irán reforzando a lo largo de la centuria hasta formar un auténtico bastión defensivo. Sin embargo, tras la experiencia del desembarco y ataque a Rota en plena Guerra de Sucesión (1702), se había puesto de manifiesto que la bahía no estaba bien guarnecida. Y esta deficiencia podía considerarse un punto débil del traslado, aunque, eso sí, la presencia de la Armada en la Isla debía contribuir a vencerla.

De hecho, en los años previos, se habían atendido las necesidades más perentorias de la defensa, con pequeñas actuaciones en algunos castillos (San Sebastián sobre todo) y baluartes de la ciudad, así como en los cuarteles que debían alojar la tropa. Durante los años de la Guerra, los trabajos irán en esta misma línea, concentrándose en buena parte sobre la zona más vulnerable del llamado Campo del Sur. La operación culminará unos años después, en 1724, cuando el recién nombrado ingeniero general, Jorge Próspero de Verboom, ponga de manifiesto la necesidad de integrar los trabajos puntuales en un proyecto, llevado a cabo más tarde por la Real Junta de Fortificaciones de Cádiz y el afamado ingeniero militar Ignacio de Sala ${ }^{54}$.

54. Cano Révora, M. ${ }^{a}$ G.: Las murallas de Cádiz en un tiempo de cambio (1693-1728). Tesis Doctoral Inédita, Universidad de Cádiz, 2015, pp. 91 y sigs.

Ediciones Universidad de Salamanca / 요 Stud. his., H. ${ }^{a}$ mod., 39, n. 2 (2017), pp. 115-152 


\section{LA CRISIS DE LOS AÑOS VEINTE}

Para paliar las ventajas concedidas a Cádiz, Felipe V dispuso una serie de medidas compensatorias en favor de Sevilla, que también le había ayudado a ganar la guerra y aún poseía un peso importante en el conjunto nacional. Entre las primeras se hallaba la presencia de dos diputados del Consulado en Sevilla:

para la expedición de sus dependencias, con participación del Tribunal [de la Casa de Contratación], al qual deberán representar sobre todo lo que ocurriere, dando regla, y forma a los litigantes no padezcan detenciones, y que sean despachadas sus instancias breve, y sumariamente, la palabra atendida, y buena fe guardada ${ }^{55}$.

En el mismo decreto se ordenaba la reducción de la cúpula consular a tres cónsules (uno de ellos, el primero, sería el prior), debiendo pertenecer los dos primeros, a la Universidad de Cargadores de la ciudad de Sevilla y el tercero a la de Cádi ${ }^{56}$. Más tarde se estipularía asimismo que las elecciones de dichos miembros siguieran haciéndose en Sevilla, y de los 30 electores escogidos para su elección, 20 lo fueran por la ciudad hispalense y solo 10 por Cádiz. Así, aunque en la ley no lo especificase, el cargo de prior estaría hasta 1743 en manos de un cargador de Sevilla. Y tras esta fecha, a la ciudad hispalense se le reforzaría con la creación de la Real Fábrica de Tabacos y la Compañía de Comercio y Fábricas de San Fernando.

Pero estas compensaciones no evitaron la polémica, que se inició muy pronto, extendiéndose a las siguientes décadas, aunque con diferente nivel de intensidad según los tiempos. De manera más o menos directa seguía activa por los años cuarenta, momento en que aún se echaban briznas a la hoguera.

Tras los primeros pasos dados por el ministro José Patiño, era preciso, pues, proveer a la consolidación de los cambios. Y esto era mucho más difícil en el ámbito comercial que en el militar, donde, por el contrario, apenas se plantearon discusiones.

No obstante las bazas a su favor que tenía la opción de Cádiz y su bahía, el asunto no iba a resultar nada fácil, gravitando como estaban sobre él los reclamos de Sevilla, los cambios ministeriales y la propia actitud titubeante del rey. En última instancia, tanta será la dependencia del Estado, que las vacilaciones producidas alrededor del traslado no se deberán únicamente a las pugnas entre Sevilla y Cádiz, a los argumentos a favor y en contra de la conveniencia de una u otra ciudad o a los resultados parciales de los enfrentamientos, sino a las propias discrepancias

55. «Decreto de S.M. de 12 de mayo de 1717», fol. 3.

56. Ibidem. 
en el seno del Gobierno y sus aledaños. Y con el rey, lógicamente, como vértice del sistema político, participando en ellas.

Los años veinte habían arrancado con otra de las reformas previstas inicialmente: la del sistema de convoyes a Indias, buscando su afianzamiento y la corrección de sus carencias con vistas a mejorar su defensa, asegurar la competitividad de las manufacturas españolas frente a las extranjeras y optimizar la percepción de impuestos por parte de la Real Hacienda. La reforma se concretará en el «Proyecto para galeones, y flotas de el Perú y Nueva España, y para navíos de registro y avisos», promulgado el 5 de abril de $1720^{57}$.

La década sería igualmente un tiempo rico en reuniones, juntas ad hoc (así, en 1722), pruebas periciales para conocer la navegabilidad del Guadalquivir (1720 y 1723), presiones ante las autoridades, acusaciones y argumentaciones diversas y, en definitiva, de un abundante número de memoriales y sus correspondientes respuestas (1722 y 1726) a cargo de cada una de las partes (Sevilla y Cádiz, con sus respectivos cabildos municipales al frente). Durante la mayoría de estos años, la permanencia de las instituciones del comercio con Hispanoamérica en Cádiz no estuvo asegurada. Hubo incluso momentos en que parecía iba a deshacerse el camino andado, como en 1725, cuando el rey firmó el decreto de reversión, que, afortunadamente para Cádiz, nunca llegó a aplicarse.

A lo largo de todo este proceso, los hombres del Gobierno o próximos a él jugaron, como ya se ha indicado, un papel decisivo, y desde este punto de vista, Cádiz seguía teniendo todas las de ganar, a diferencia de lo que sucederá en el reinado de Carlos III, cuando se refuercen otras ideas y llegue al poder una nueva generación contraria al monopolio gaditano. De ahí que las crisis coyunturales de los años veinte se inicien o resuelvan con las salidas o entradas en los cargos, que, dicho sea de paso, se producen con una extraordinaria rapidez.

Tal había ocurrido en 1718-1719, preámbulo de la primera crisis, la del tándem Alberoni-Pez-Patiño, tras la caída del primero con motivo de su fracaso en la política mediterránea y la ausencia de Cádiz del tercero por esos años. No es mera coincidencia que, en 1720, encabezara el almirante sevillano Manuel López

57. Suele considerársele obra de Patiño. En él se adoptan varias medidas: rebaja importante de impuestos a favor de las manufacturas españolas, aumento de los derechos de importación de la plata y el oro, supresión y restructuración de algunos gravámenes, protección de los navíos mercantes con buques de guerra (dos, Almiranta y Capitana), ampliable a otros dos más, establecimiento de un calendario fijo regulando las salidas, entradas y estadías de los convoyes; asegurar las suplencias por las ausencias producidas en los navíos y reafirmación de la feria de Jalapa, que, sin embargo, quedaría suprimida por Real Orden publicada en 1722 , tras experiencias negativas con los convoyes que siguieron a la promulgación del «Proyecto». 
Pintado la defensa de la causa de su ciudad ante la Corte (más tarde lo hará su sucesor el marqués de Thous $)^{58}$.

La crisis se reiterará en 1723, coincidiendo con la muerte del almirante Pez, y en 1724 con la abdicación del rey, la consiguiente subida al trono de su hijo Luis I en enero de ese mismo año, y la recuperación del poder por parte de los sevillistas: J. B. Orendaín, amigo de Uztáriz, el gran defensor teórico-práctico de la causa hispalense, y Luis de Miraval, presente en alguno de los sondeos del Guadalquivir, elevados a la Secretaría de Estado y la Presidencia de la Casa de la Contratación respectivamente. Son ellos quienes logran precisamente arrancar a Felipe V, recién regresado al poder tras la inesperada muerte de su hijo, la Real Orden de reversión de 21 de septiembre de 1725, aunque únicamente se refiera a la Casa de la Contratación, y no al Consulado ni a la cabecera del monopolio, cuya continuidad se daba por hecho ${ }^{59}$.

Desde Madrid, Herrera salvaría la causa gracias a sus contactos en la Corte y con el rey, así como a la redacción de sendas Representaciones en 1726, el mismo año que la de Sevilla anónima (¿Ustáriz? ¿Thous?); de las primeras, una al menos publicada, ambas con argumentos similares. De esta forma, la Real Orden de 1725 quedó finalmente revocada. Quien había sido hombre fuerte del Gobierno en 1725, el barón de Ripperdá, no obstante su enemistad con José Patiño y Grimaldo, se había puesto al parecer de parte de Cádiz ${ }^{60}$. En cualquier caso, duró poco tiempo en el poder, que se vio obligado a abandonar en 1726.

Sin embargo, la caída de Ripperdá no menguaría del todo la ventaja obtenida por la causa gaditana; de hecho, tendría ventaja en el nuevo equipo de Gobierno: Orendaín, probablemente el único sevillista del grupo, pasaba a la Secretaría de Estado; el inefable José Patiño, en pleno auge de su poder, sumaría la de Marina e Indias a la de Hacienda y a la Superintendencia, y Baltasar Patiño, hermano de José y marqués de Castelar, permanecería en la de Guerra $(1720)^{61}$. En cambio, el Consejo de Indias, poco afecto generalmente a la causa gaditana, nombraría a Varas como presidente de la Casa de Contratación ${ }^{62}$.

Pero junto a las personas, había habido alrededor del traslado ofertas de dinero posiblemente clandestinas para presionar a los ministros y a la Corona a favor de uno u otro de los contendientes. Los representantes de ambas ciudades ante la

58. Ravina, M.: op. cit., pp. 74 y 99.

59. La explicación más verosímil de la no inclusión del Consulado en el decreto tiene que ver con el control ejercido por Sevilla por esta institución, a pesar de su traslado a Cádiz.

60. Ravina, M.: op. cit., pp. 104-105.

61. Escudero, J. A.: Los orígenes del Consejo de Ministros en España. Madrid, 1979, p. 90.

62. Ravina, M.: op. cit., p. 104. 
Corte utilizaron sin ambages este recurso (así, Francisco Manuel de Herrera y al parecer también el marqués de Thous en 1725$)^{63}$.

En cualquier caso, por lo que respecta a Cádiz, pocas veces a lo largo de su historia se había mostrado tan combativa como en la defensa de su derecho al monopolio y a los dos organismos del comercio complementarios. Los tiempos jugaban a su favor. A medida que la ciudad y su bahía se consolidaban en el ámbito financiero-mercantil, aprovechando el desarrollo económico y comercial imparable que se experimentaba en la centuria, y se dotaban asimismo, por mandato gubernamental, de los elementos capaces de servir de soporte a las reformas borbónicas, resultó cada vez más difícil ganarle la partida. Se trataba, en cierta forma, de hechos consumados. Pero Sevilla sí que podía combatir a su rival, al menos indirectamente. ¿Cómo? Controlando como hizo las elecciones a la cúpula consular, colocando en cuando pudiese hombres de su causa al frente de la Casa (cuyo poder, sin embargo, Patiño había hecho menguar y a lo que el Intendente ya se había anticipado) o subrayando las debilidades de Cádiz.

Este, a través de Francisco Manuel de Herrera, se defendía asimismo, haciendo ver que la protesta, más que por los comerciantes en sí, estaba impulsada por una minoría de regidores del ayuntamiento hispalense, que simultaneaban este oficio con el de cosecheros, sin ser verdaderos cargadores a Indias, y controlaban a la vez el Consulado al que pertenecían, temiendo con su instalación en Cádiz la pérdida del manejo (sic) que venían ejerciendo sobre él ${ }^{64}$.

Para asegurar la independencia de los Tribunales (sic), el representante gaditano propondría la incompatibilidad entre ambos cargos, en el cabildo y el Consulado, y que los miembros de este hubiesen viajado a Indias antes de poder matricularse en él, y fuesen solventes en temas de comercio como condición sine qua non para ocupar puestos consulares. Tales cualidades faltaban, en opinión de Herrera, en los cargos sevillanos ${ }^{65}$.

\section{UNA POLÉMICA AÑADIDA: LOS COMERCIANTES EXTRANJEROS Y SUS HIJOS}

Por el contrario, una parte importante del argumentario de Sevilla contra Cádiz venía reposando sobre el nocivo papel que, en su opinión, desempeñaban los extranjeros en la ciudad y en la Carrera de Indias. A su presión achacaron la decisión misma del traslado, por el beneficio que estos obtendrían. Y razón no les

63. Idem, pp. 99-101.

64. Herrera, F. M.: Representación que la Muy Noble y Muy Leal, pp. 6; 50v; 59v.; 64v y 65.

65. Idem, pp. $65 \mathrm{v}-66$.

Ediciones Universidad de Salamanca / 뾰 Stud. his., H. ${ }^{a}$ mod., 39, n. 2 (2017), pp. 115-152 
faltaba a los representantes de Sevilla, aunque la crítica hubiese debido centrarse más bien en la colonia francesa, a la sazón, posiblemente, la más implicada en el hecho por las razones más arriba expresadas.

Así pues, al margen de los intereses políticos que se movían en la Corte, en Sevilla se conocían perfectamente la importancia de los extranjeros en el comercio de la bahía. De hecho, también allí la habían experimentado. Sin embargo, no se dudó en utilizar ese argumento, haciendo hincapié en los aspectos más negativos de dicha presencia, pues no en vano se trataba de un monopolio que, recordemos, pertenecía en exclusividad a los españoles, aunque los extranjeros establecidos en Cádiz hubiesen acrecentado aquí su poder y su número (Herrera lo sitúa a comienzos de los años veinte en un $25 \%$ del vecindario gaditano) ${ }^{66}$, a partir del último tercio del siglo xvir. Lo que venía sucediendo día a día alrededor de la ciudad y su bahía no era para Sevilla sino una violación permanente de la base misma del sistema, aunque sus efectos viniesen sintiéndose desde antes. El simple hecho de la continuidad en el tiempo del fraude, de la tolerancia institucional hacia él y de la participación de muchos colaboradores necesarios, lo hacían prácticamente inconmovible y hasta cierto punto irreformable.

A este argumento sumaba Sevilla otros, como el de los perniciosos efectos prácticos que tenían para la industria española las injerencias extranjeras o los peligros que se podían derivar si alguna de las potencias con presencia en Cádiz entraba en conflicto con la Monarquía. La representación hispalense lejos de cercenar la crítica a los franceses, que tan influyentes se habían mostrado en la primera década de la centuria, prefirió abrirla a los extranjeros en su conjunto. Y no contenta con ello, quiso dirigir su mirada hacia sus descendientes.

La intromisión de los llamado jenízaros en la Carrera de Indias, se puso sobre el tapete, coincidiendo en el tiempo con la polémica en torno al traslado, a lo largo de las décadas de los años veinte y cuarenta. Aunque no era la primera vez que se hacía (de hecho fue un tema reiterativo desde el siglo xvI), podemos ahora ver en su emergencia y en la virulencia especial con que reaparece un reflejo más, duradero en el tiempo, de la pugna entre las dos ciudades andaluzas en torno a lo sucedido en $1717 \mathrm{y}$ a sus efectos.

Sin que el debate interurbano hubiese llegado a su fin, la diferencia con respecto a lo visto antes está en los agentes que ahora asumen el relevo en la controversia sobre el tema: por encima de todos el Consulado, que seguía estando controlado en su cúpula y en sus electores por cargadores avecindados en Sevilla; indirectamente la Casa de la Contratación y el Consejo de Indias, al estar también implicados en

66. Idem, p. $12 \mathrm{v}$. 
el asunto de la participación en el comercio de los descendientes de extranjeros nacidos en España.

Así pues, la batalla se centraría preferentemente sobre estos, a los que muchos continuaban considerando extranjeros sin más por su servidumbre comercial y financiera con respecto a los países de origen de sus ascendientes, no obstante haber sido autorizados legalmente a participar como naturalizados (leyes de 14 de agosto de 1620 y del 1 de noviembre de 1681), en un comercio que era monopolio exclusivo de los españoles, acusándoles de haber incurrido en abuso manifiesto a la hora de obtener licencias para viajar a las Indias. Algunos detractores iban incluso más allá. Vázquez Morales, encargado de la secretaría responsable de los asuntos relacionados con el Perú, recordaba «el natural afecto de el extranjero a su propia Patria» y su desafección (sic) a España.

En este contexto propicio, el motivo que se aprovechó para avivar el debate fue lo acontecido en 1720 en torno de la flota de 19 navíos (tres de ellos de guerra) comandada por Chacón, primera que se hacía a la mar tras la promulgación del «Reglamento» de ese mismo año arriba aludido ${ }^{67}$. Antes de su salida de Cádiz, le llegaron quejas al Consulado acerca de los embarcados en ella con mercancías a su consignación, siendo recusadas sus licencias ante el Consejo. Previamente, el Consulado había ordenado recoger alguna de ellas, a la espera de ver los testimonios aportados. Según sus representantes, no bastaba con demostrar que se era nacido en España mediante la correspondiente partida de bautismo, ni tampoco con la autorización conyugal para el viaje, sino que era preciso justificar ser verdaderamente natural del país y que el padre no solo habita en él, sino que está avecindado ${ }^{68}$.

La publicación en ese mismo año de la nueva reglamentación, que contemplaba una subida notable de impuestos para los productos extranjeros y una reducción sustanciosa de los pagados por los hispanos, debió animar a los jenízaros a volcarse en la participación en dicha flota. Con tal motivo, el Consulado enviaría una representación al Consejo en ese mismo año, previniéndole de la posible participación de los hijos de extranjeros con sus envíos en el referido convoy (por supuesto, no era la única vez que esto ocurría: algo similar había sucedido ya antes en la flota de Antonio Serrano de 1717). Pero lejos de pedir la suspensión de la salida (la flota estaba próxima a partir), el Consulado demandaba que se remediara el problema sin perjudicarla.

67. García-Mauriño Mundi, M.: La pugna entre el Consulado de Cádiz y los jenízaros por las exportaciones a Indias (1720-1765). Sevilla, 1999, pp. 51 y ss.

68. AGI, Escribanía de Cámara, 1057-a, fols. 11 y 14.

Ediciones Universidad de Salamanca / 요 Stud. his., H. ${ }^{a}$ mod., 39, n. 2 (2017), pp. 115-152 
A instancias de Felipe V, Chacón condicionaría entonces la participación de los sospechosos a que pagasen unas determinadas fianzas; pero, al regreso de la flota, el Consulado ordenó su cancelación para quienes hubiesen obtenido la licencia, ante la necesidad de dirimir la actuación de la Casa en la concesión de la misma, por considerar que había actuado con negligencia, contrariando la ley, al tenerse solo en cuenta en la autorización el lugar de nacimiento, pero no los orígenes familiares. Los jenízaros, así pues, habían terminado sustituyendo a los naturales ${ }^{69}$. De hecho, en la década de los veinte, las habilitaciones proliferarían especialmente ${ }^{70}$.

El Consulado criticaba asimismo a la Casa de la Contratación de haber concedido tales licencias sin tener competencia para ello, ya que en puridad era un derecho que pertenecía al Consejo desde la ley de 22 de septiembre de $1722^{71}$. Por su parte, este pedía cuentas a la Casa acerca de las habilitaciones para comerciar que había venido otorgando en los últimos 20 años, a pesar de que el Consulado le había suplantado, pues le constaba a ese un buen número de irregularidades cometidas, entre ellas las de haberse expedido a nombre de las mujeres de los solicitantes y sin aportar los papeles requeridos. Sin embargo, contradictoriamente, el propio Consulado, convertido a su vez en demandante, no había tenido empacho al parecer en dar participación a los jenízaros en la propia institución, a pesar de las leyes que lo prohibían ${ }^{72}$. En definitiva, la polémica ponía de manifiesto no solo las ambigüedades de carácter legal existentes en torno al monopolio y a la jurisdicción de las diferentes instituciones que lo sostenían, sino también las irregularidades que se venían cometiendo en torno a él. Por tanto, a veces esas mismas instituciones se acusaban mutuamente de invadir sus respectivas prerrogativas.

Entre tanto, el 12 de febrero de 1722, los representantes de los jenízaros habían remitido al Consejo un escrito defendiéndose. En él distinguían los cargadores privilegiados adscritos al Consulado instalado en Cádiz del resto de comerciantes españoles con las Indias (del «Comercio de España»). Su argumento principal era que sus encomiendas solo perjudican a los primeros, debido a la competencia que les hacían; pero no a los segundos. De ahí que fuera en los primeros donde reposara el ataque contra ellos descansara en los miembros de la asociación mercantil. Les achacaban su debilidad a la hora de competir, razón última de su autodefensa. Como solución, solicitaban los jenízaros el «restablecimiento (de)

69. Idem, fols. 14 y 15 .

70. 58 sobre 81 (GARCía-Mauriño: op. cit., pp. 23-25).

71. AGI, Escribanía de Cámara, 1057-a, fol 11.

72. García-Mauriño: op. cit., p. 15. 
un nuevo Cuerpo de Comercio», que les incluyera con plenitud de derechos. En su opinión, en la flota de Chacón el Consulado habría impedido el envío de autos al Consejo de Indias, donde los hijos de extranjeros que embarcaron en la misma probaban su naturaleza española, habiendo dado lugar a la amenaza del presidente del Consejo al procurador de la Casa de la Contratación ${ }^{73}$. En 1724 se encargaría a Patiño que revisara las leyes concernientes a la participación de extranjeros y jenízaros en el comercio con las Indias, con vistas a buscar una solución. Aquel optaría finalmente por una fórmula drástica.

Así, la controversia se saldó temporalmente de manera desfavorable para los jenízaros. El 23 de septiembre de 1729, estando el rey en la bahía de Cádiz, se firmará en El Puerto de Santa María, quedando ratificado por la vía reservada al año siguiente, el decreto que contemplaba la reforma del comercio, o mejor la creación de una «nueva planta», donde, entre otras cosas, se precisaba quiénes estaban autorizados a participar en el comercio con las Indias ${ }^{74}$. Se excluía de forma tajante a los extranjeros y a los jenízaros, quedando el Consulado, cuya posición al respecto ya conocemos, encargado oficialmente de decidir sobre las admisiones. El resultado más visible fue una larga lista de comerciantes autorizados a comerciar con América, la primera después de muchos años, de la que eran extrañados los extranjeros y los jenízaros. Bajo vigencia de la misma, en los años treinta, a pesar de que las controversias no cesaron del todo, al menos disminuyeron en su intensidad.

Sin embargo, a comienzos de los años cuarenta, se estaba fraguando un nuevo equilibrio en el corazón de la Carrera de Indias. El control sobre la matrícula consular para excluir a los jenízaros estuvo oficialmente vigente hasta 1742 , fecha de la publicación de la Real Cédula de 20 de abril de ese mismo año revocándolo, y admitiéndoles de nuevo al comercio, aunque se siguiera confiando al Tribunal del Consulado el control de la admisión ${ }^{75}$. Por su parte, la Casa de la Contratación dictaba al siguiente año varios autos complementarios (el 26 de marzo y 18 de junio), sobre la manera de realizar las nuevas matrículas en el Consulado. 1744 será clave. De él saldría un organismo renovado: cambio en la cúpula consular con el nombramiento del primer prior vecino de Cádiz, y el 1 de febrero de dicho año, la rebaja de 20 a 10 del número de electores sevillanos, la participación de

73. AGI, Escribanía de Cámara, 1057 a, fol. 24.

74. La «planta» o reglamento del Consulado donde se introducía esta reforma rezaba así: «sobre los motivos que concurren para exterminar la introducción de los que con título de jenízaros se han ingerido en el Comercio de la Carrera de Indias». Obsérvense las expresiones utilizadas en el texto.

75. AGI, Consulados, 446, fols. 333-334.

Ediciones Universidad de Salamanca / 요 Stud. his., H. ${ }^{a}$ mod., 39, n. 2 (2017), pp. 115-152 
otros vecinos de diversas localidades de la provincia de Cádiz en las elecciones y el traslado de la sede de estas a Sanlúcar ${ }^{76}$.

Poco antes, hacia 1742-1743, el Consulado, ligado todavía al modelo antiguo, libraba una nueva campaña (¿la última importante?) contra los descendientes de extranjeros, como respuesta a un «Papel» (sic) anónimo que había aparecido, defendiendo la causa de los jenízaros. Los ánimos estaban ya muy excitados.

El Consulado recordaba ser los españoles en exclusiva los dueños (sic) del comercio de las Indias, puesto que lo habían ganado por los méritos y sacrificios de sus ascendientes. A dicha Corporación correspondía conservarlo para sus dueños los españoles ${ }^{77}$. Arremeterá asimismo contra los jenízaros, a los que difama llamándoles «bastardos del Príncipe», recordando ser «más Españoles los que descienden de otros tales», y acusándoles de perjudicar a la Hacienda, al no pagar al regreso de los barcos de Indias los derechos correspondientes, y sobre todo de suplantar a los comerciantes españoles en las encomiendas de mercancías ${ }^{78}$.

Por su parte, los jenízaros se defenderían denunciando al Consulado por el cobro de gravámenes que no le pertenecía ${ }^{79}$, y lanzando casi a la vez un dardo envenenado contra los comerciantes de Cádiz, y sobre todo contra los matriculados en el Consulado, usufructuarios del monopolio, al distinguir en dicho «Papel» de nuevo entre los verdaderamente afectados (los encomenderos), al ser el comercio de Cádiz un comercio fundamentalmente de mediación, y el conjunto del «Comercio de España»; es decir, el resto de comerciantes españoles, incluidos quienes no gozaban en Cádiz de los mismos privilegios que los matriculados. Es más, consideraban que el número de los españoles «que siguen la Carrera de las Indias» no era fidedigno y cabía por tanto desconfiar de él (¿̇nsinuaban por tanto los jenízaros que había personas matriculadas como comerciantes, que no lo eran verdaderamente? $)^{80}$.

Por el contrario, el Consulado señalaba el sacrificio que los españoles habían hecho para servir a los interesados en su servicio con solvencia y fidelidad, a costa no pocas veces de su propia conveniencia. Por el contrario, los comerciantes extranjeros no habían dejado de producir quiebras en los suyos, arrastrando en

76. Desde 1744 hasta 1784,30 vecinos de la provincia de Cádiz ocuparán dicho puesto, aunque solo 15, es decir, el 50\% de ellos, fuesen de la capital. En cualquier caso, sea través de unos u otros, el predominio gaditano será ahora incontestable. Heredia Herrera: Sevilla, pp. 148 y ss.

77. AGI, Escribanía de Cámara, 1057 a, fol. 24.

78. Idem, fols. 19 y 20.

79. Idem, fol. 24.

80. Idem, fols. 19 y 20. 
ellas «porciones de caudal de Españoles». De sus actuaciones fraudulentas y estrategias daba cuenta el Consulado. Y es que los jenízaros, con frecuencia jóvenes inexpertos, tienen engañados a quienes ponen en ellos la confianza de su negocio. Más aún, el Consulado, exacerbado, extenderá su crítica a quienes casan a su hija con extranjero, acusándoles de buscar con ello enriquecerse ${ }^{81}$.

Tales ataques, sin embargo, eran poco realistas, habida cuenta del replanteamiento del Gobierno sobre la participación de los descendientes de extranjeros en el comercio monopolístico, reconociendo de nuevo su derecho, aceptado desde antes por la propia ley, a desarrollar su labor mediadora (encomiendas) en la Carrera de Indias, al igual que los «hijos de Españoles antiguos».

\section{LA CONCURRENTE REFORMA DE LA MARINA}

Entre tanto, ceñida al ámbito militar, la reforma de la Marina concurrente con la del comercio, no experimentaría los mismos sobresaltos. La mano firme de Patiño y sus «discípulos» hizo sentir su presencia. Por otro lado, no existían aquí los intereses encontrados que suscitaba el traslado. Y Sevilla en este asunto poco tenía que decir.

Entre 1717-1718, a pesar de las interrupciones, Patiño pudo desarrollar una labor rápida y eficaz en todos los órdenes, a fin de cumplir con el objetivo de convertir a Cádiz y la bahía en la plataforma y eje de la política naval y comercial de la Corona en los términos que se habían planteado.

Para ello hubo de actuar, casi al unísono, sobre varios frentes: $1 .^{\circ}$ reorganización administrativa de la Armada a través de un proceso de centralización, $2 .^{\circ}$ obtención de marinos y marineros bien cualificados, y $3 .^{\circ}$ aumento del contingente de navíos hasta acercarlo al que convenía a una potencia como España con importantes compromisos ultramarinos. Estas tareas, sin embargo, se prolongarán a lo largo de toda la centuria con resultados varios. El arranque, las primeras décadas del empeño, resultarían decisivas.

Mientras la Carrera de Indias podía autofinanciarse gracias a sus propios recursos, a la vez que, bien organizada como se pretendía, podía igualmente incrementar los ingresos de la Corona por el desarrollo de la actividad económica y el paralelo crecimiento de los impuestos derivados de él, no podía ocurrir lo mismo, al menos directamente, con la Armada. Para la puesta en marcha del programa arriba trazado, lo primero era contar con los necesarios recursos económicos. Así, solo durante el primer cuarto de siglo se constata un considerable aumento del

81. Idem, fols. 20,21 y 22 . 
MANUEL BUSTOS RODRÍGUEZ

EL TRASLADO DE LA CASA DE LA CONTRATACIÓN Y DEL CONSULADO DE INDIAS Y SUS EFECTOS

EN EL CONTEXTO DE LA NUEVA PLANTA DE LA MARINA Y DEL COMERCIO AMERICANO

presupuesto de la Marina, al pasar este de los 900.000 a los 20 millones de reales entre los años 1701 y $1724^{82}$.

La reorganización administrativa de la Armada había comenzado muy tempranamente. Hacia ella apuntará la Instrucción de $1720^{83}$ y, sobre todo, las ordenanzas de $1725^{84}$, relativas a la formación del Cuerpo del Ministerio de la Marina. Allí se establecerán les funciones del cuerpo de intendentes ${ }^{85}$. Cádiz no solo tiene un papel decisivo en la reforma en sí, sino que se convierte en el lugar de redacción y posterior publicación de estos documentos. En 1726 se decide igualmente la creación de los tres departamentos marítimos, a comenzar por el de Cádiz, que se mantendrán a lo largo de todo el siglo xviII. Y en 1737, fallecido Patiño el año antes, se crea el Almirantazgo, a imitación de los que habían sido erigidos en otros países.

Por lo que se refiere al segundo elemento de la reforma, la formación de los miembros de la Marina, el primer paso importante llegó también en el siempre paradigmático año de 1717 con la inauguración en Cádiz de la Compañía y la Academia de Guardias Marinas, cuya idea inicial parece haber partido del cardenal Alberoni. En ese mismo año, ni corto ni perezoso, Patiño publica sus correspondientes ordenanzas, situando al astrónomo francés Louis Godin al frente. En la Instrucción correspondiente del año 1718 se organizará como cuerpo de carácter militar.

La Academia servirá igualmente a las aspiraciones de la pequeña y mediana nobleza, que la Corona había deseado atraerse, y así, filtrando los ingresos, sus miembros, unidos a los hijos de marinos, acrecentarán sus filas sin mucha dilación. Para febrero de 1717, contaba con los 37 primeros alumnos, en su mayoría

82. Saralegui y Medina, L.: Historia del Cuerpo Administrativo de la Armada. El Ferrol, Imprenta Ricardo Pita, 1867, p. 68.

83. Aquí aparecen las normas para regular la organización y el funcionamiento de todos los órganos administrativos que dependían del Intendente General.

84. Ordenanzas e Instrucciones generales formadas de Real Orden de lo que se debe observar por los Intendentes y demás ministros de Marina y dependientes del ministerio de ella, según lo respectivé al empleo y encargo de la Real Hacienda y cuenta y razón de ella, Cádiz, el 1 enero 1725. El contenido del texto en GuZMán, I.: «Normativa contable en la Armada española durante el período 1700-1850: especial referencia a la administración de provisiones», De Computis. Revista Española de Historia de la Contabilidad, 5, 2006, pp. 74 y ss.

85 El cargo de designación real, con residencia en Cádiz, tenía competencias sobre la construcción de navíos y la dotación de armamento, la organización de los arsenales y almacenes, así como sobre el personal necesario para estas funciones y el control financiero de las operaciones (Vid.: Ordenanzas e Instrucciones Generales formadas de Real Orden de lo que se debe observar por los Intendentes y demás Ministros de Marina y dependientes del Ministerio de ella, según lo respectivé al empleo y encargo de la Real Hacienda, y cuenta y razón de ella. Cádiz, Jerónimo de Peralta, Impresor Mayor, ed. de 1736, caps. I y II). 
vascos, gracias a sus vínculos tradicionales con la Armada y a su adscripción a la idea de hidalguía universal ${ }^{86}$. Transcurridas las primeras décadas de vida, en 1748, coincidiendo con la apertura en Cádiz del primer Real Colegio de Cirugía de la Armada, se publicaba el plan de estudios de los cadetes, y apenas cinco años después se proveía a la mejora de su formación científica con el establecimiento en la ciudad del Real Observatorio de Marina, cuyo director será el propio capitán de la Compañía y los profesores los mismos responsables de aquel.

Pero sin barcos no había política naval que valiera la pena. Como ya vimos, el proyecto reformista íntegro pasaba por aumentar el tamaño de la flota de guerra. Sin embargo, Patiño, siguiendo una opinión muy extendida, tras las primeras iniciativas, creyó insuficientes a tal propósito el número y capacidad de los astilleros existentes. Así, coincidiendo con la crisis de los años veinte en torno al traslado y a los jenízaros, establecería el marco necesario para la creación de nuevos astilleros, condición sine qua non para la gran época de la construcción naval del marqués de la Ensenada. Una vez más, la Bahía desempeñará en ello un papel eminente, dando cauce a un desarrollo constructivo sin parangón.

El punto de partida será la promulgación de las ordenanzas de arsenales de 1723. Sin apenas retraso, a partir del año siguiente, se ponía en marcha el nuevo primer astillero naval en La Carraca, aprovechando las dificultades de acceso a la zona, la experiencia en el carenado y la existencia de dependencias próximas al lugar en la Isla de León y Puerto Real para la fabricación de velamen y cordelajes ${ }^{87}$. Pero esas fábricas eran insuficientes, siendo preciso mejorar sus instalaciones, empresa que veremos desarrollarse fundamentalmente a lo largo de los años treinta. Era necesario encontrar trabajadores y oficiales especializados, pero sobre todo directores y capitalistas que pudiesen gestionar y hacer frente a gastos numerosos. La iniciativa para su búsqueda queda a cargo de las autoridades (Francisco Varas y Rodrigo Torres), aunque Patiño tendrá una vez más un puesto destacado, favoreciendo las propuestas de los particulares atraídos por el negocio (Francisco Digret, el irlandés Mateo Mullen o Juan Burnabi). Los esfuerzos no resultaron vanos del todo: la producción aumentó en términos generales y la construcción de barcos se desarrolló paralelamente, sobre todo desde mediados de la centuria, si bien hubo que completarla con importaciones ${ }^{88}$. A La Carraca seguirían otros astilleros repartidos por España.

86. VÁlgoma, D. de la: Real Compañia de Guardiamarinas y Colegio Naval. Catálogo de pruebas de Caballeros aspirantes. Madrid, Instituto Histórico de Marina, 1944.

87. Quintero GonzÁlez, J.: La Carraca. El primer astillero ilustrado español (1717-1776). Madrid, 2004.

88. Quintero González, J.: Jarcias y Lonas, pp. 51-71, 79-91 y 119-129.

Ediciones Universidad de Salamanca / 요 Stud. his., H. ${ }^{a}$ mod., 39, n. 2 (2017), pp. 115-152 
El embajador británico en España, Mr. Keene, supervisor atento de estos progresos, nos ofrece un buen testimonio de los efectos de este impulso constructor, al informar a su Gobierno en 1731 que el número de barcos, incluidos los de tonelaje reducido, sobrepasaba las 50 unidades, de las que casi la mitad habían sido destinadas a la bahía de Cádiz ${ }^{89}$.

En resumidas cuentas, ambas reformas, la del monopolio comercial y la de la Marina, proyectadas como complementarias, habían seguido caminos diferentes: dadas las circunstancias de partida, sumergida en una polémica incesante en el primer caso, más calma y eficaz en el segundo, donde el terreno era más bonancible. Al final ambas reformas unidas prepararían la necesaria plataforma para el desarrollo mercantil y naval experimentado por Cádiz y su bahía a partir de los años centrales de la centuria, singularizando al conjunto de la zona.

\section{BibliografíA}

Alonso Aguilera, M. A.: La conquista y el dominio español de Cerdeña 1717-1720: introducción a la política española en el Mediterráneo posterior a la Paz de Utrecht. Valladolid, 1977.

Anes, G.: El Antiguo Régimen: Los Borbones. Madrid, 1975, p. 340.

Apestegui Cardenal, C.: «Arquitectura y construcción navales en la España Atlántica, el siglo XVII y primera mitad del xviII. Una nueva sistematización», Proceedings. International Symposium on Archeology of Medieval and Modern Ships of Iberian Atlantic Tradition, en http://www.patrimoniocultural.pt/media/uploads/trabalhosdearqueologia/18/16.pdf, 16.1.2017, pp. 163-212.

Barrio Gozalo, M.: «El cardenal Alberoni y España. Política religiosa y carrera eclesiástica», Hispania Sacra, LXIII:1278, 2011, pp. 205-234.

Benítez Barea, A.: «El impacto de la Guerra de Sucesión en Cádiz, Felipe V de Borbón (1701-1746)», en Pereira, J. L. (coord.): Felipe V de Borbón 1701-1746. Actas (Congreso San Fernando, Cádiz de 27 de noviembre a 1 de diciembre de 2000). Córdoba, Ayuntamiento de San Fernando y Universidad de Córdoba, 2002, pp. 479-500.

Bernardo Ares, J. M. de: «La Monarquía Hispánica de Ryswick y el Estado Español de Utrecht: dos formas diferentes de configurar política y económicamente a España», en Pereira, J. L. (coord.): Felipe V de Borbón 1701-1746. Actas (Congreso San Fernando (Cádiz) de 27 de noviembre a 1 de diciembre de 2000). Córdoba, Ayuntamiento de San Fernando y Universidad de Córdoba, 2002, pp. 503-518.

BÉthencourt Massieu, A.: Patiño en la política internacional de Felipe V. Valladolid, 1954.

89. Cit. por Anes, G.: El Antiguo Régimen: Los Borbones. Madrid, 1975, p. 340.

Ediciones Universidad de Salamanca / 요 Stud. his., H. ${ }^{a}$ mod., 39, n. 2 (2017), pp. 115-152 
MANUEL BUSTOS RODRÍGUEZ

EL TRASLADO DE LA CASA DE LA CONTRATACIÓN Y DEL CONSULADO DE INDIAS Y SUS EFECTOS EN EL CONTEXTO DE LA NUEVA PLANTA DE LA MARINA Y DEL COMERCIO AMERICANO

Bustos Rodríguez, M.: «De Sevilla a Cádiz: hacia el cambio de funcionalidad en el seno del monopolio andaluz con América». Estudios de la Universidad de Cádiz ofrecidos a la memoria del profesor Braulio Justel Calabozo, 1998, pp. 487-498.

Bustos Rodríguez, M.: «La ciudad de Cádiz y su contribución a la Guerra de Sucesión, 1704-1705», Anales de la Universidad de Cádiz, 1, 1984, pp. 139-148.

Bustos Rodríguez, M.: Nueva Historia de Cádiz. Vol. III: Época Moderna. Un emporio atlántico en Europa. Madrid, 2014.

Cano Révora, M. ${ }^{a}$ G.: Las murallas de Cádiz en un tiempo de cambio (1693-1728). Tesis Doctoral Inédita, Universidad de Cádiz, 2015.

Castanedo Galán, J. M.: Guarnizo, un astillero de la Corona. Madrid, Ed. Naval, 1993.

Castellano, J. L.: «El gobierno en los primeros años del reinado de Felipe V: La influencia francesa», en Pereira, J. L. (coord.): Felipe V de Borbón 1701-1746. Actas (Congreso San Fernando (Cádiz) de 27 de noviembre a 1 de diciembre de 2000). Córdoba, Ayuntamiento de San Fernando y Universidad de Córdoba, 2002, pp. 129-142.

Castro, A. de: Vida del almirante D. Andrés de Pes. Cádiz, 1879.

Cosandey, F.: Monarchies espagnole et française: 1550-1714. París, Atlande, 2001.

Crespo Solana, A.: «El comercio y la Armada de la Monarquía: la Casa de Contratación y la Intendencia General de la Marina de Cádiz, 1717-1750», Cuadernos monográficos del Instituto de Historia y Cultura Naval. La Casa de Contratación de Sevilla, aproximación a un centenario (1503-2003), 39, 2002, pp. 63-78.

Crespo Solana, A.: «La acción de José Patiño en Cádiz y los proyectos navales de la Corona del siglo XviII», Trocadero: Revista de Historia Moderna y Contemporánea, 6-7, 1994-1995, pp. 35-50.

Crespo Solana, A.: La Casa de Contratación y la Intendencia General de la Marina en Cádiz (1717-1730). Cádiz, Universidad, 1996.

Decreto de Su Magestad de 12 de mayo de 1717. Dirigido al Consejo de Indias, mandando que el Consulado, y Casa de Contratación, que estaban en Sevilla, passen a Cádiz; y declarando al mismo tiempo los Ministros, y demás personas de que se han de componer cada uno de estos Tribunales, $y$ dependencias en que han de entender, como también las que se han de dirigir por el Intendente General de la Marina.

Escudero, J. A.: Los orígenes del Consejo de Ministros en España. Madrid, 1979.

García-Mauriño Mundi, M.: La pugna entre el Consulado de Cádiz y los jenízaros por las exportaciones a Indias (1720-1765). Sevilla, 1999.

Guzmán, I.: «Normativa contable en la Armada española durante el período 1700-1850: especial referencia a la administración de provisiones», De Computis. Revista Española de Historia de la Contabilidad, 5, 2006, pp. 65-146.

Hanotin, G.: Jean Orry. Un homme des finances royales entre France et Espagne (17011705). Córdoba, 2009.

Heredia Herrera, A.: Élite y poder: comerciantes sevillanos y asociaciones mercantiles en el siglo XVIII», Archivo Hispalense: Revista histórica, literaria y artística, 70, 213, 1987, pp. 69-92.

Heredia Herrera, A.: Sevilla y los hombres del Comercio (1700-1800). Sevilla, 1989.

Ediciones Universidad de Salamanca / 
MANUEL BUSTOS RODRÍGUEZ

EL TRASLADO DE LA CASA DE LA CONTRATACIÓN Y DEL CONSULADO DE INDIAS Y SUS EFECTOS EN EL CONTEXTO DE LA NUEVA PLANTA DE LA MARINA Y DEL COMERCIO AMERICANO

Herrera, F. M. de: Representacion que la muy Noble, y muy Leal Ciudad de Cadiz haze al Rey nuestro Señor sobre las pretensiones deducidas por la muy Noble, y muy Leal Ciudad de Sevilla, para la translación del Comercio, y Carrera de Indias, Juzgado, y Tabla de ella; Tribunales de Contratacion, y Consulado; Comercio Universal de Naciones Estrangeras; Aduanas; Tercio de Buque en Flotas, y Galeones, con otros varios assumptos. Escrita por D.--, Diputado de Cadiz en la Corte, año de 1726... Cádiz, Diputación Provincial, 1984.

Iglesias Rodríguez, J. J.: «El “Canal Prodigioso”: el caño del Trocadero en el siglo XviII», Revista de Estudios Puertorrealeños, 1, 2015, pp. 47-77.

Kuethe, A. J. y Serrano, J. M.: «El astillero de La Habana y Trafalgar», Revista de Indias, 241, 2007, pp. 763-776.

Luzzi Traficante, M.: «Los hombres del catastro y de la nueva monarquía: Patiño y Ensenada en la gestión doméstica de la Monarquía del siglo xviıI», C. T. Catastro, 82, 2014, pp. 49-68.

Navarro García, L.: «La Casa de la Contratación en Cádiz», en La burguesía mercantil gaditana (1650-1868). Actas del XXXI Congreso luso-español para el progreso de las ciencias. Cádiz, 1976, pp. 41-82.

Ordenanzas e Instrucciones generales formadas de Real Orden de lo que se debe observar por los Intendentes y demás ministros de Marina y dependientes del ministerio de ella, según lo respectivé al empleo y encargo de la Real Hacienda y cuenta y razón de ella. Cádiz, el 1 enero 1725, Jerónimo de Peralta, Impresor Mayor, ed. de 1736.

Ozanam, D.: «La política exterior de España en tiempo de Felipe V y Fernando VI», en JOver zamora, J. M. a (dir.): La época de los primeros Borbones. La nueva Monarquía y su posición en Europa (1700-1759). Madrid, 1985, vol. XIX de la Historia de España R. Menéndez Pidal, pp. 443-699.

Ozanam, D. y MÉzin, A.: Économie et négoce des Français dans l'Espagne de l'Époque Moderne. Instructions et mémoires officiels relatifs au commerce en Espagne de la gestion de Colbert (1669) au Pacte de Famille (1761). París, 2011.

Pando Villarroya, J. L.: La Intendencia de la Armada. Madrid, 1982.

Pérez Fernández-Turégano, C.: Patiño y las reformas de la administración en el reinado de Felipe V. Madrid, 2016.

Patiño y Rosales, J.: «Exposición Reservada», en Rodríguez Villa, A.: Patiño y Campillo. Reseña histórico-biográfica de estos dos ministros de Felipe $V$ formada con documentos $y$ papeles inéditos y desconocidos en su mayor parte, por... Madrid, 1882, pp. 19 y ss.

Pérez-Mallaína, P. E.: Política naval española en el Atlántico. 1700-1715. Sevilla, 1982.

Professione, A.: Il ministero in Sapagna é il proceso del Cardinale Giulio Alberoni. Turín, 1898.

Proyecto para galeones y flotas del Perú, y Nueva España, y para navios de registro, y avisos, que navegaren a ambos Reynos. Año de 1720. Impresso: De orden del Rey.

Pulido Bueno, I.: José Patiño: el inicio del gobierno politico-económico ilustrado en España. Huelva, 1998. 
Quintero González, J.: Jarcias y lonas. La renovación de la Armada en la babia de Cádiz 1717-1777. Cádiz, Publicaciones del Sur, 2003.

Quintero GonzÁlez, J.: La Carraca. El primer astillero ilustrado español (1717-1776). Madrid, 2004.

Ravina Martín, M. (ed. y estudio preliminar): El pleito Cádiz Sevilla por la Casa de la Contratación. Memorial de Frco. Manuel Herrera 1726. Cádiz, 1984.

Ribot García, L. A.: «Orígenes políticos del testamento de Carlos II. La gestación del cambio dinástico en España». Discurso leído el día 17 de octubre de 2010 en la recepción pública...». Madrid, 2010.

Rodríguez Villa, A.: Patiño y Campillo. Reseña histórico-biográfica de estos dos ministros de Felipe $V$ formada con documentos y papeles inéditos y desconocidos en su mayor parte, por... Madrid, 1882.

Salva y Riera, J.: Patiño. Madrid, 1942.

San Martín de Artiñano, F. J.: La defensa militar de la Carrera de Indias. La infantería de Armada y el tercio de galeones (1521-1717). Madrid, 2015.

Saralegui y Medina, L.: Historia del Cuerpo Administrativo de la Armada. El Ferrol, Imprenta Ricardo Pita, 1867.

Serrano Mangas, F.: Los galeones de la Carrera de Indias, 1650-1700. Sevilla, 1986.

Tapias Herrero, E.: El almirante López Pintado (1677-1745). Sevilla, 2017.

VÁlgoma, D. de la: Real Compañía de Guardiamarinas y Colegio Naval. Catálogo de pruebas de Caballeros aspirantes. Madrid, Instituto Histórico de Marina, 1944.

Walker, G. J.: Política española y comercio colonial: 1700-1789. Barcelona, 1979.

Ediciones Universidad de Salamanca / 요 Stud. his., H. ${ }^{a}$ mod., 39, n. 2 (2017), pp. 115-152 